Hydrol. Earth Syst. Sci. Discuss., doi:10.5194/hess-2016-160, 2016

Manuscript under review for journal Hydrol. Earth Syst. Sci.

Published: 7 July 2016

(c) Author(s) 2016. CC-BY 3.0 License.

\title{
Comparison of uncertainty in multi-parameter and multi-model ensemble hydrologic analysis of climate change
}

\author{
Younggu Her ${ }^{1}$, Seung-Hwan Yoo $^{2}$, Chounghyun Seong ${ }^{3}$, Jaehak Jeong ${ }^{4}$, Jaepil Cho ${ }^{5}$, Syewoon Hwang ${ }^{6}$
}

$5 \quad{ }^{1}$ Department of Agricultural and Biological Engineering \& Tropical Research and Education Center, University of Florida, Homestead, FL 33031, United States

${ }^{2}$ Department of Rural and Bio-Systems Engineering, Chonnam National University, Gwangju 500-757, Republic of Korea

${ }^{3}$ Department of Biological Systems Engineering, Virginia Tech, Blacksburg, VA 24601, United States

${ }^{4}$ Texas A\&M AgriLife Research, Texas A\&M University, Temple, TX 76502, United States

$10 \quad{ }^{5}$ Research Department, APEC Climate Center, Busan 612-020, Republic of Korea

${ }^{6}$ Department of Agricultural Engineering, Gyeongsang National University, Jinju 660-701, Republic of Korea

Correspondence to: Seung-Hwan Yoo (yoosh15@jnu.ac.kr)

\begin{abstract}
Quantification of uncertainty in ensemble based predictions of climate change and the corresponding hydrologic impact is necessary for the development of robust climate change adaptation plans. Although the equifinality of hydrological modeling has been discussed for a long time, its impact on the hydrologic analysis of climate change has not been studied enough to provide clear ideas that represent the relative contributions of uncertainty contained in both multi-GCM (general circulation model) and multi-parameter ensembles toward the projections of hydrologic components. This study demonstrated that the uncertainty in multi-GCM (or multi-model) ensembles could be an order of magnitude larger than that of multi-parameter ensembles for predictions of direct runoff, suggesting that the selection of appropriate GCMs should be

20 much more emphasized than the selection of a parameter set among behavioral ones when projecting direct runoff. When simulating soil moisture and groundwater, on the other hand, equifinality in hydrologic modeling was more influential than uncertainty in the multi-GCM ensemble. Also, uncertainty in a hydrologic simulation of climate change impact was much more closely associated with uncertainty in ensemble projections of precipitation than that in projected temperature, indicating a need to pay closer attention to the precipitation data for improvement of the reliability of hydrologic predictions.

25 From among 35 GCMs incorporated, this study identified GCMs that contributed the most and least to uncertainty in an assessment of climate change impacts on the hydrology of 61 Ohio River watersheds, thereby exhibiting a framework to quantify contributions of individual GCMs to the overall uncertainty in climate change modeling.
\end{abstract}


Hydrol. Earth Syst. Sci. Discuss., doi:10.5194/hess-2016-160, 2016

\section{Introduction}

General circulation models (GCMs) have been developed by many national and international research institutions and agencies and served as useful, and probably the only, tools to predict future climate change (Murphy et al., 2004; Pierce et al.,

5 2009; Overland et al., 2010). Since each GCM has been developed based on its own assumptions and unique mathematical representations of physical climate system processes, different climate change estimations are provided (Hawkins and Sutton, 2009). Thus, climate model selection is not only a watershed modeler's first decision in a hydrologic analysis of climate change, but it is also one of the most critical tasks though it is often undertaken with limited information regarding quality and reliability (Murphy et al., 2004). The Intergovernmental Panel on Climate Change (IPCC) launched the Coupled

10 Model Intercomparison Project Phase 5 (CMIP5) in the fifth Assessment Report (AR5), whereby a multi-model ensemble analysis was facilitated through the provision of climate model outputs that comply with community standards (Taylor et al., 2012; IPCC, 2013; Sansom et al., 2013). The multiple general circulation model (multi-GCM) ensembles has served as a framework for accommodating probabilistic approaches in interpretation of climate change predictions and decision-making processes, and many studies have attempted to quantify uncertainty and identify its sources (Nohara et al., 2006; Christensen and Lettenmaier, 2007; Tebaldi and Knutti, 2007; Graham et al., 2007; Sheshukov et al., 2011; Chong-Hai and Ying, 2012; Harding et al., 2012; Velázquez et al., 2013). Ensemble averaging can improve the accuracy of a climate projection by allowing GCM errors cancel each other out (Pierce et al., 2009). However, the approach often does not employ all models available thus may underestimate uncertainty and/or produce a bias in the ensemble prediction (Tebaldi and Knutti, 2007; Vander Linden and Mitchell, 2009). Further, interpretation of an ensemble averaging prediction remains challenging due to

20 "the lack of consensus on combing models" (Knutti et al., 2010; Parker, 2010).

Because of the global nature of the climate system and the complexity of the underlying climate physics, climate change impact assessments are often implemented in continental and regional extents, which, however, are not the scales at which most hydrologic analyses and water resources managements are carried out (Hostetler, 1994; Xu, 1999a; 1999b; Arora and Boer, 2001; Stone et al., 2001; Guo et al., 2002; Varis et al., 2004; Nohara et al. 2006; Döll and Schmied, 2012; Oubeidillah

25 et al., 2013). A large-scale analysis may not consider detailed hydrological processes, and localized impacts may not be effectively represented at such scale (Varis et al., 2004; Hulme, 2005; Young et al., 2009). For instance, hillslope processes including infiltration and overland flow transport are more dominant and influential in hydrology and ecosystem of a small watershed, while channel routing and groundwater flow are more important processes controlling the overall hydrologic response of a large watershed (Huff et al., 1982; Ward, 1984; Meyer et al., 2007; Richardson and Danehy, 2007; Frisbee et

30 al., 2011). In addition, it is reasonable to assume a homogeneous landscape for a hillslope, whereas a large-scale watershed tends to have great heterogeneity in its landscape (Hostetler, 1994). The responses of individual landscape units of a large watershed are likely to be intermingled with others and dampened through prolonged overland and channel processes 
Hydrol. Earth Syst. Sci. Discuss., doi:10.5194/hess-2016-160, 2016

Manuscript under review for journal Hydrol. Earth Syst. Sci.

Published: 7 July 2016

(c) Author(s) 2016. CC-BY 3.0 License.

(Frisbee et al., 2011; Stanfield and Jackson, 2011; Frisbee et al., 2012). The hydrological responses of local head watersheds to climate change would, therefore, be clearly explained at small spatial scales.

Many different hydrological models, from distributed to lumped, have been utilized in climate change studies: the variable infiltration capacity (VIC) model (Christensen and Lettenmaier, 2007; Hayhoe et al. 2007; Oubeidillah et al., 2013),

5 Hydrologiska Byråns Vattenbalansavdelning (HBV) model (Bergström et al. 2001; Arheimer et al., 2005; Graham et al., 2007; Akhtar et al., 2009), and the Soil and Water Assessment Tool (SWAT) model (Stone and Hotchkiss, 2003; Graiprab et al., 2010; Mango et al., 2011; Sheshukov et al., 2011; Van Liew et al., 2013), as well as simple models such as ABCD and Budyko (Fu et al., 2007, Sankarasubramanian and Vogel, 2002; Tigkas et al., 2012; Liu and Cui, 2011; Liu and Yang, 2010; Dooge, 1992; Poff et al., 1996). Complicated models can simulate detailed hydrologic processes, but the sizable input data

10 and parameter requirements tend to result in uncertainty (Her and Chaubey, 2015). Simpler models are therefore preferable as long as they can provide predictions regarding hydrological variables and components of interest at the required levels of accuracy and detail, especially when the overall far future hydrologic responses of a watershed are of interest.

An understanding of the sources and influences of uncertainty helps to identify the ways that can efficiently improve the robustness and reliability of a climate change impact analysis, whereby the subsequent development of climate change

15 mitigation strategies and water resource management plans can be more effective. Equifinality is one of the main sources of uncertainty in hydrologic modeling, and many methods have been proposed to quantify equifinality and the resulting uncertainty (Beven, 2006; Sadegh and Vrugt, 2013). While it is known that equifinality decreases with an increase in the number of observations and a decrease in the number of calibration parameters, equifinality is inevitable, and its impact is substantial in hydrologic modeling (Her and Chaubey, 2015). There are only a few known studies about the influence of

20 equifinality of hydrological models on climate change impact assessment. Poulin et al. (2011) demonstrated that hydrologic model structure uncertainty is more influential than parameter uncertainty on assessment of climate change impact in a snow dominated river basin. Maurer et al. (2010) found that a climate change impact assessment could be significantly affected by hydrologic model selection and parameter calibration. Several studies showed that selection of hydrologic model (structural uncertainty) is much more influential than GCM selection in assessments of climate change (Kay et al., 2009; Gosling et al.,

25 2011; Najafi et al., 2011). Chen et al. (2010) and Dobler et al. (2012) demonstrated that, in terms of a climate change impact assessment, hydrologic model parameter uncertainty is the least influential; notably, though, the numbers of the arbitrarily selected unique parameter sets incorporated for their studies were only 10 and 20, respectively, indicating high possibility of underestimation in the assessments of the equifinality impacts. In addition, most hydrological analyses of climate change uncertainty employed a single or a few study watersheds and/or the phase 3 of the Coupled Model Intercomparison Project

30 (CMIP3) in their case studies even though it has been several years since the latest climate models of CMIP5 built under RCP scenarios were first released, meaning that the applicability of the study results is possibly limited.

This study compared the significance of selections of GCMs and hydrological model parameters (equifinality) on hydrological assessment of climate change by quantifying uncertainty in multi-GCM and multi-parameter ensemble 
Hydrol. Earth Syst. Sci. Discuss., doi:10.5194/hess-2016-160, 2016

Manuscript under review for journal Hydrol. Earth Syst. Sci.

Published: 7 July 2016

projections for weather and hydrology of multiple watersheds selected within the Ohio River basin. In this study, 35 ensemble members including 22 CMIP5 GCMs and their variants (hereafter 35 GCMs) were considered, and 61 study watersheds were incorporated to show the variability of the quantified uncertainty across the different watersheds. A simple, monthly water balance model, $\mathrm{ABCD}$, was employed as a mathematical representation of the mechanisms that control the responses of the hydrologic components to climate variability. The behavioral parameter sets of the water balance model that were developed for each watershed were identified using the Generalized Likelihood Uncertainty Estimator (GLUE) framework (Beven and Freer, 2001), and multiple thresholds were applied to see the sensitivity of the equifinality contributions to subjectivity.

\section{Methods and Materials}

\subsection{Study area}

The Ohio River basin is located in the Eastern Corn Belt and extends across nine states from Illinois to New York, between the latitudes $36^{\circ} 07^{\prime}$ and $42^{\circ} 26^{\prime}$ North, and the longitudes $77^{\circ} 50^{\prime}$ and $89^{\circ} 01^{\prime}$ 'West. The basin drains a primarily agricultural area of $374,000 \mathrm{~km}^{2}$ including several large cities into the Mississippi River and eventually the Gulf of Mexico.

15 For this study, 61 study watersheds within the Ohio River basin were selected for the consideration of the drainage areas, locations, availability of streamflow measurements, and applicability of the ABCD model (Figure 1). The total drainage area of the selected watersheds is $41,341 \mathrm{~km}^{2}$, (average size is $678 \mathrm{~km}^{2}$ ) which is $11 \%$ of the entire basin's drainage area. The daily precipitation and temperature observations that were obtained from 103 weather stations associated with the basin were used for statistical downscaling of GCM climate projections. The climate of the Ohio basin varies from humid subtropical

20 (north-east) to humid continental (southwest), and the annual average temperature and precipitation across the basin are $11.3^{\circ}$ $\mathrm{C}$ and $1,032 \mathrm{~mm}$, respectively.

Chien et al. (2013) predicted that the annual streamflow of the agricultural watersheds in the Midwestern United States would decrease by as much as $40 \%$ under the Speical Report on Emission Scenarios (SRES) of 26 GCM projections. Panagopoulos et al. (2015) found that the crop productivity of the Ohio River basin could decrease by $20 \%$ under climate projections; they also found large amounts of uncertainty in the sediment and nutrient loads of the basin that were projected by seven CMIP5 GCMs. Ebner et al. (2015) investigated the impacts of future climate changes, represented by four CMIP3 GCMs, on the hydrology of the Upper Scioto River Basin that drains $8,337 \mathrm{~km}^{2}$ into the Ohio Basin; depending on the GCMs used in their study, the annual streamflow projections varied by a factor of two to three, indicating a large uncertainty in the multi-GCM ensembles for the study basin. Kunke et al. (2013) investigated the future climate scenarios of the

30 Midwest U.S. projected by 15 CMIP3 GCMs, and found wide variations of the annual precipitation and temperature projections, depending on the GCMs that are employed. 
Hydrol. Earth Syst. Sci. Discuss., doi:10.5194/hess-2016-160, 2016

Manuscript under review for journal Hydrol. Earth Syst. Sci.

Published: 7 July 2016

(c) Author(s) 2016. CC-BY 3.0 License.

\subsection{Multi-GCM ensemble}

Over the last several years, the climate projections from the GCMs participating in the CMIP3 and CMIP5 have been employed for climate change impact assessments at both regional and local scales (Lopez et. al, 2009; Johnson et. al., 2011). CMIP5, the latest climate data, is expected to promote multi-GCM frameworks by providing a range of projected climate

5 sciences (Taylor et al., 2012). In this study, climate projections for the weather gage stations associated with the study watersheds were obtained by downscaling the 35 climate change outputs selected from 22 GCMs of the CMIP5 (Figure 1 and Table 1). In addition, two RCP scenarios (RCP 4.5 and RCP 8.5) that have been commonly adopted as forcing scenarios for the CMIP5 GCMs were employed to consider uncertainty in the future social conditions (van Vuuren et al., 2011), leading to the formulation of 35 climate projections for each of the combinations of the RCP scenarios and watersheds in this

10 study (Table 1).

Because of the inconsistency regarding the spatial resolutions between GCM data and a climate change impact assessment, GCM data are often downscaled to finer resolutions, and often into existing weather stations (Christensen et al., 2008; Maraun, 2013). For this study, the CMIP5 GCM outputs (precipitation, maximum and minimum temperatures) of the Ohio River study watersheds were statistically downscaled over the period from 1950 to 2099 using the hybrid semi-parametric 15 approach proposed by Ho et al., (2012), which is considered computationally efficient and easy to implement (Diaz-Nieto and Wilby, 2005). Using Eq. (1), the approach matches the location (mean), scale (variance), and shape (skewness) parameters of the climate change data with those of the historical data to preserve the consistency of the data's statistical features over long term periods:

$\hat{X}_{o}^{\prime}=\mu_{o}+\frac{\sigma_{o}}{\sigma_{\mu}}\left(X_{m}^{\prime}-\mu_{m}\right)$,

20 where $\mathrm{X}, \mu$, and $\sigma$ respectively represent the variable of interest, mean, and standard deviation of a climate, the subscripts of $\mathrm{o}$ and $\mathrm{m}$ respectively signify the observable and simulated climate variables of interest, the superscript of ", " indicates a future period, and the symbol of “ " represents a bias corrected variable. Once the GCM downscaling into the existing weather stations was completed, the multi-GCM ensemble averages of the weather variables (precipitation and temperature) and the hydrologic components were determined by averaging the downscaled projections with equal weights according to the "one model, one vote" weighting scheme (Sansom et al., 2013).

\subsection{Hydrologic model}

A simple hydrologic model, $\mathrm{ABCD}$ was prepared to simulate the long-term monthly hydrologic responses of the 61 study watersheds to projected climate changes (Thomas, 1981). In the ABCD model, available water $(W W, \mathrm{~mm})$ of the current month is defined as a summation of precipitation $(P P, \mathrm{~mm})$ of the current month $(t)$ and soil water content $(S S, \mathrm{~mm})$ of the previous month $(t-1)$ (Eq. (2)), while the evapotranspiration opportunity of the current month $(Y Y, \mathrm{~mm})$ is determined by a summation of actual evapotranspiration and soil water content of the current month (Eq. (3)), as follows:

$W W_{t}=P P_{t}+S S_{t-1}$ 
Hydrol. Earth Syst. Sci. Discuss., doi:10.5194/hess-2016-160, 2016

and

$Y Y_{t}=P E T_{t}+S S_{t}=\frac{W w_{t}+b}{2 a}-\sqrt{\left(\frac{W w_{t}+b}{2 a}\right)^{2}-\frac{W W_{t} b}{2 a}}$,

where the $a$ and $b$ parameters represent "propensity for runoff to occur well before the soil is saturated to capacity" $(0 \leq$ $a \leq 1$ ) and "upper limit of storage in the unsaturated zone above the groundwater level," or "upper bound of the summation 5 of actual evapotranspiration and soil moisture storage," respectively (Thomas, 1981). PET $T_{t}$ represents the potential evapotranspiration $(\mathrm{mm})$ that is calculated using an equation such as the following Penman and Hargreaves equation (Eq. (4)):

$P E T=e \cdot P E T_{E Q}$,

where $e$ is a calibration parameter that is newly introduced to the original $\mathrm{ABCD}$ model, and $P E T_{E Q}$ is the potential

10 evapotranspiration estimation provided by the PET equation. Due to its simplicity, the following Hargreaves equation was selected for a calculation of the monthly PET in this study (Eq. (5)):

$P E T_{E Q}=0.000938(T A V+17.8)(T M X-T M N)^{0.5} R_{a}$,

where $T A V$ is average monthly temperature $\left({ }^{\circ} \mathrm{C}\right), T M X$ is maximum monthly temperature $\left({ }^{\circ} \mathrm{C}\right), T M N$ is minimum monthly temperature $\left({ }^{\circ} \mathrm{C}\right)$, and $R_{a}$ is extraterrestrial radiation $\left(M J m^{-2} m_{o n t h} h^{-1}\right)$.

15 In the $\mathrm{ABCD}$ model, the soil water content is proportional to the evapotranspiration opportunity, and it exponentially increases with increases of the potential evapotranspiration rate (Eq. (6)), as follows:

$S S_{t}=Y Y_{t} \exp \left(\frac{-P E T_{t}}{b}\right)$

Groundwater storage $(G G, \mathrm{~mm}$ ) and streamflow (or total runoff: $Q Q, \mathrm{~mm}$ ) are calculated as functions of the available water and the evapotranspiration opportunity using Eq. (7) and Eq. (8), respectively, as follows:

$20 G G_{t}=G G_{t-1}+c\left(W W_{t}-Y Y_{t}\right)-d G G_{t}$

and

$Q Q_{t}=(1-c)\left(W W_{t}-Y Y_{t}\right)+d G G_{t}$,

where $c$ is a parameter that is equivalent to the baseflow index and represents a fraction of the streamflow contributed by the groundwater, and $d$ is the groundwater residence time that is proportional to the baseflow recession constant.

25 Evapotranspiration $(E T, \mathrm{~mm})$ is then regarded as the difference between the precipitation and the total runoff. Further, the middle term on the right side of Equation 7 is groundwater recharge, and the left- and right-side terms on the right side of Equation 8 represent direct runoff $(D R, \mathrm{~mm})$ and groundwater discharge $(G W, \mathrm{~mm})$, respectively.

\subsection{Multi-parameter ensemble}

The ABCD model prepared for each watershed was calibrated to the monthly streamflow measured at the watershed outlet.

30 A sampling based optimization algorithm, Shuffled Complex Evolution - University Arizona (SCE-UA) (Duan et al., 1992; 1994), was used to explore the parameter space and to find sets of the five parameters, $a, b, c, d$, and $k_{c}$ that provide 
Hydrol. Earth Syst. Sci. Discuss., doi:10.5194/hess-2016-160, 2016

Manuscript under review for journal Hydrol. Earth Syst. Sci.

Published: 7 July 2016

(c) Author(s) 2016. CC-BY 3.0 License.

acceptable model performance statistics during the calibration period from 1990 to 2012. In the calibration, multiple parameter sets that satisfy the predefined performance requirements were identified as behavioral sets under the GLUE framework (Beven and Freer, 2001). These behavioral sets are defined as "equally good" and "equally acceptable" (Her and Chaubey, 2015). To take subjectivity into account in the parameter uncertainty estimation, the combinations of an absolute threshold of the minimum NSE of 0.67 and the four different relative thresholds of the best $10 \%, 7.5 \%, 5 \%$, and $2.5 \%$ were applied to identify the behavioral parameter sets out of those sampled in the calibration. It is worth noting that this study initially included 156 candidate watersheds from within the Ohio River basin for which USGS streamflow gage data are available, and those watersheds with $\mathrm{ABCD}$ models that did not meet the absolute performance criterion (NSE of at least 0.67) were not included in this study.

\section{$10 \quad 2.5$ Quantification of uncertainty in multi-parameter and multi-GCM ensembles}

A range of the difference between the maximum and minimum values was used as a measure of the amounts of uncertainty in the ensemble predictions that were made using multiple GCMs and behavioral parameter sets. For this study, uncertainty in the multi-parameter ensembles was first quantified by calculating the ranges (upper limits minus lower limits) of the monthly hydrographs simulated using the behavioral parameter sets that had been previously identified for each combination

15 of GCMs and study watersheds (Figure 2). Then, an average hydrograph of multi-parameter ensembles was derived for each GCM and study watershed combination, and the range of the variations in the average hydrographs across the GCMs for each watershed was regarded as the amounts of uncertainty in the multi-GCM ensembles (Figure 2). Thus, the uncertainty amounts quantified for two difference sources, a multi-parameter ensemble and a multi-GCM ensemble, became independent of each other, which allows direct comparison of the two uncertainty quantities.

20 The contribution of each GCM model to the GCM model selection uncertainty was quantified by comparing the uncertainty amounts (ranges) in either the GCM ensemble predictions of the monthly climate variables or the hydrologic components that are made with/without the use of each GCM (Equation (9)), as follows:

$U^{Q}\left(G C M_{x}\right)=U^{Q}\left(G C M_{\forall x \in S}\right)-U^{Q}\left(G C M_{x \notin S}\right)$,

where $U^{Q}\left(G C M_{x}\right)$ is the uncertainty quantities in the GCM ensemble predictions for either a climate variable or a hydrologic

component $Q$ (e.g., PP and $\mathrm{QQ}$ ), which are solely attributed to $G C M_{x} ; U^{Q}\left(G C M_{\forall x \in S}\right)$ is the total uncertainty in the entire GCM ensemble; and $U^{Q}\left(G C M_{x \notin S}\right)$ is the measured uncertainty in the GCM ensemble for which $G C M_{x}$ is excluded. The relationships between the uncertainty quantities in the ensemble projections of the climate variables and those in the ensemble projections of the hydrologic components were then investigated to see which climate variable (precipitation, maximum and minimum temperatures) exerts the most significant influence on the hydrologic prediction uncertainty. 
Hydrol. Earth Syst. Sci. Discuss., doi:10.5194/hess-2016-160, 2016

Manuscript under review for journal Hydrol. Earth Syst. Sci.

\section{Results and Discussion}

\subsection{Projected precipitation and temperature}

The precipitation projections made by the 35 GCMs were averaged by the months and by the study watersheds to investigate the overall trends of future precipitation in the Ohio River basin. The annual average precipitation of the Ohio River

5 watersheds from 2020 to 2099 was projected to increase by $6.8 \%$ and $8.8 \%$ under the RCP 4.5 and RCP 8.5 scenarios, respectively. The projected monthly precipitations showed large seasonal variations, with up to $14 \%$ and $19 \%$ increases under the RCP 4.5 and RCP 8.5 scenarios, respectively (Figures 3 (a) and (b)). The increase rates were higher in winter and spring than in summer, which is in agreement with the findings of Kunkel et al. (2013).

The annual temperature was projected to increase by $2.2^{\circ} \mathrm{C}$ and $3.6^{\circ} \mathrm{C}$ on average in the watersheds under the RCP 4.5 and

10 RCP 8.5 scenarios, respectively, compared to the historical average temperature of $12^{\circ} \mathrm{C}$ (Table 2), which was also consistent with the Kunkel et al. (2013). The overall predictions regarding the monthly maximum and minimum temperatures showed an increase, although a decrease was predicted for some watersheds. The variations of the minimum temperature across the study watersheds (ranges of the values or heights of the boxes in the box and whisker plots in Figure 3) were larger than those of the maximum temperature. The amount of the variations of the maximum temperature across the

15 watersheds was relatively consistent over months, but the minimum temperature largely varied according to the watersheds during winter, indicating that the climate variability of the Ohio River watersheds would be more evident regarding the minimum temperature.

The monthly ensemble precipitation and temperature projection made by using the 35 GCMs for the entire 61 watersheds, as well as the "03232500" watershed that was selected as an example because of its representability in terms of location (the

20 middle of the study watershed group) and size $\left(366 \mathrm{~km}^{2}\right.$ : Figure 1(c)), are plotted in Figures 4 and 5, respectively. The amount of the variations of the projected precipitation did not change over time, but under RCP 8.5, the amount was larger than that under RCP 4.5 (Figures 4 and 5). Under the RCP 4.5 scenario, the GCMs predicted that the overall precipitation and temperature of the Ohio Basin watersheds would increase at the rates of $0.51 \mathrm{~mm} / \mathrm{dec}$ ade and $0.28^{\circ} \mathrm{C} / \mathrm{dec}$ ade, respectively, which correspond to the slopes of the linear trend lines of Figure 4, and that the rates increased to 1.25 $\mathrm{mm} /$ decade and $0.64^{\circ} \mathrm{C} /$ decade for precipitation and temperature, respectively, under the RCP 8.5 scenario. As seen in Figure 5, the variations of the precipitation ensemble were greater than those of the temperature ensemble, indicating the projection of precipitation is more susceptible to the selection of GCMs than is temperature projection.

\subsection{Projected hydrologic changes}

Monthly hydrographs of the hydrologic components that were generated using multiple GCMs and the behavioral 30 parameters of the ABCD model were averaged to construct multi-parameter and multi-GCM ensemble streamflow hydrographs for each watershed (Figure 6; Tables 2 and 3). It is worth clarifying that the ranges and heights of the boxes 
Hydrol. Earth Syst. Sci. Discuss., doi:10.5194/hess-2016-160, 2016

Manuscript under review for journal Hydrol. Earth Syst. Sci.

Published: 7 July 2016

(c) Author(s) 2016. CC-BY 3.0 License.

presented in the box and whisker plots that subsequently appear in this paper represent the projection variations across the 61 study watersheds.

The projections regarding the overall annual averages of PP (precipitation), QQ (total runoff or streamflow), DR (direct runoff), GW (groundwater), and ET (evapotranspiration) showed increases compared with those of the baseline (or historical) period under the RCP 4.5 and RCP 8.5 scenarios (Table 2). The projected increase rates of the hydrologic components including QQ, DR, and GW were greater than those for PP $(6.8 \%$ and $8.8 \%$ for the RCP 4.5 and RCP 8.5 scenarios, respectively), which is in agreement with $\mathrm{Fu}$ et al. (2007), indicating that the precipitation changes were amplified in the runoff hydrographs (Table 2). The PET (potential ET) projections showed increases at rates similar to those of the TAV (average temperature) and PP, while the ET did not change as much as the TAV, PP, and PET because of the projected

10 decreases of the infiltration and SS (soil water contents) (Table 2). The amount of available water in the watersheds was expected to increase by $1.6 \%$ and $1.5 \%$ for the RCP 4.5 and RCP 8.5 scenarios, respectively, implying that the overall amount of the available water in the Ohio River watersheds may not decrease in the future due to the projected increases in PP.

Simulated ensemble hydrographs showed unique watershed variations depending on the hydrologic component (Figure 6).

15 For the cases of QQ, DR, GW, PET, ET, and WW (available water) (Figure 6), the spatial (across watersheds: heights of boxes, and the ranges between the maximum and minimum depths) and seasonal variations provided by the RCP 8.5 scenario and the far future (2070 to 2079) projection were generally somewhat larger than those provided by the RCP 4.5 scenario and the near future projection, respectively, indicating a greater uncertainty regarding far future hydrologic projections that are under extreme emission scenarios. The projections of DR showed greater seasonal variations than those of GW, which is in sound agreement with our watershed hydrology understandings, whereby the response of surface runoff to precipitation is more direct than that of groundwater to precipitation. The high seasonal variations found in the PET projections, ranging from $5 \mathrm{~mm}$ to $350 \mathrm{~mm}$, were damped in the ET projections due to the interactions between soil particles and water that are expressed by the water-holding capacity of soil (Figure 6). The projections of SS and WW were widely and symmetrically distributed across the watersheds during each month, demonstrating the hydrologic variety of the selected watersheds. The annual and monthly watershed hydrology projections show that the multi-GCM and multi-parameter ensemble averages could provide reasonable descriptions of the overall hydrologic response of the Ohio River watersheds to climate projections.

The monthly projections of the multi-parameter and multi-model (or multi-GCM) ensembles regarding the hydrologic components were compared with the historical data to attain an understanding of the overall projected seasonal changes of

30 the hydrology of the Ohio River watersheds (Table 3; Figures 7 and 8). QQ, DR, GW, and ET were projected to increase in all of the months, but SS was projected to decrease in most of the months, with the exception of January and February (Table 3 and Figure 7). WW of the watersheds was projected to decrease in June and July under the RCP 4.5 scenario, and in June, July, October, and November under the RCP 8.5 scenario. The increased rates of QQ and DR were larger than those of PP for all of the months, indicating that the amplified climate change impact on QQ is mainly attributed to the increases of DR 
Hydrol. Earth Syst. Sci. Discuss., doi:10.5194/hess-2016-160, 2016

Manuscript under review for journal Hydrol. Earth Syst. Sci.

Published: 7 July 2016

(c) Author(s) 2016. CC-BY 3.0 License.

(Figures 7 and 8). In contrast with DR, the increased rates of GW were relatively low during winter, but they were higher than those of DR in summer, June, and July. The projected increase of the ET was relatively large in winter and spring, which corresponds to the temperature projection. The increased ET caused a decrease of SS, with the exception of January and February for which a small amount of ET was shown, implying an agricultural drought would be deepened in the

5 watersheds; furthermore, water management needs to be more emphasized for maintaining the agricultural productivity of the Corn Belt areas in the future.

\subsection{Uncertainty of hydrologic model parameter selection}

The behavioral parameter values of the ABCD models developed for the 61 study watersheds were aggregated by the parameters to develop the overall parameter posterior distributions (Figure 9). The mode of the posterior distribution of

10 parameter $a$ that is related to the infiltration capacity was the highest in the narrowest value range, and that of parameter $d$ for the control of groundwater flow showed the lowest mode with the widest value range. Considering the hydrologic meanings of $a$ and $d$ in the ABCD model (Thomas, 1981), such findings indicate infiltration excess mechanism is dominant in the watersheds, and the proportions of groundwater to streamflow are relatively variable and uncertain across the study watersheds. The posterior distribution of $b$ had a symmetric bell shape with a mode in the range from 200 to 500, meaning

15 that the maximum monthly storage capacity in the watersheds is $350 \mathrm{~mm}$ on average. The parameter $c$ values were distributed around 0.1 , ranging from 0.0 to 0.6 , indicating that the groundwater contribution to streamflow is approximately $10 \%$, but that it is also highly variable across the watersheds. The posterior distribution of $e$, introduced to adjust the ET values, was relatively symmetric around 1.0, but a tail was present from 1.5 to 2.0. For this study, the PET was estimated using the Hargreaves equation, followed by a calibration of the streamflow measurements using the parameter $e$. The posterior distribution showed that the Hargreaves equation that was used to calculate the PET provided sound estimations with respect to the water balance modeling for which the ABCD model was used; furthermore, though, the PET could also be overestimated or underestimated by as much as $50 \%$, depending on the watershed.

Uncertainty in the projections of the multi-GCM and multi-parameter ensembles of hydrologic components was first quantified in the unit of depth by the study watersheds, then, it was normalized by dividing the depths by the precipitation

25 depths for the purpose of a fair across-watershed comparison and quick approximations of uncertainty with known precipitation depths (Figure 10 and Figure 11). It is worth clarifying that the average values represent the overall uncertainty in the Ohio River watersheds, and the height of each box represents the across-watershed variations of the uncertainty in the box and whsker plots (Figure 10).

The overall average uncertainty in the monthly multi-parameter ensemble streamflow (QQ) projections for the 61 study 30 watersheds varied from $9.2 \%(8.63 \mathrm{~mm})$ to $13.4 \%(11.93 \mathrm{~mm})$ of monthly precipitation depths under RCP 4.5 (Figure 10). Variations of the streamflow projection uncertainty amounts across the watersheds were relatively large in winter; no significant difference was found in the amounts of uncertainty between the QQ projections under RCP 4.5 and RCP 8.5 
Hydrol. Earth Syst. Sci. Discuss., doi:10.5194/hess-2016-160, 2016

Manuscript under review for journal Hydrol. Earth Syst. Sci.

Published: 7 July 2016

(c) Author(s) 2016. CC-BY 3.0 License.

scenarios. The amount of uncertainty in the QQ projections was smaller than those in the DR projections, but they were larger than those in the GW projections, indicating that DR is more sensitive to parameter uncertainty than GW.

The PET projection showed a larger uncertainty compared to those of QQ, DR, or GW particularly in summer. The PET projections also showed great spatial variations across the latitudes between $36^{\circ} 07^{\prime} \mathrm{N}$ and $42^{\circ} 26^{\prime} \mathrm{N}$ within the Ohio River basin; alternatively, the uncertainty in the actual ET projections was relatively constant over all of the months and was somewhat larger in winter than in summer. ET was restricted by SS that was low in summer when soil was dry, and this regulated the variations of the uncertainty in the ET across the watersheds; moreover, compared with summer, the variation of ET was somewhat larger during winter when SS was relatively high. Uncertainty in SS did not largely vary by the seasons due to the water-holding capacity of the soil layers. Since WW mainly consisted of SS, the amounts and seasonal trends of their uncertainty are similar to each other.

\subsection{Uncertainty in climate model selection}

The selection of climate model was an order of magnitude more influential on uncertainty in the QQ, DR, and ET projections than that of parameter selection, but it was not always the case for GW and PET (Figures 10 to 12). In the case of QQ, the overall average uncertainty in the monthly multi-GCM ensemble projection ranged from 113\% (99.3 $\mathrm{mm}$ ) to $164 \%$ (160.4 $\mathrm{mm}$ ) of monthly precipitation under RCP 4.5 (Figure 11). Uncertainty in the QQ projections was greater in winter than other seasons, and it was dominated by the GCM selection uncertainty (or the uncertainty in the ensemble projections) in DR. GW was relatively less responsive to GCM selection compared to QQ, DR, and ET (Figures 11 and 12). The influence of GCM selection on ET was far greater than that on the PET since ET is controlled by not only temperature but also the SS that is sensitive to GCM selection. The monthly variation patterns of uncertainty in PET were opposite to those of uncertainty in DR for both the multi-GCM and multi-parameter ensembles, implying that the influence of the PET uncertainty on DR projections is limited (Figures 10 and 11). Uncertainty in the WW projections due to GCM selection was 2 to 4 times larger than uncertainty in the PP projections, indicating the significance of GCM selection in a climate change impact analysis.

As the threshold values for the identification of behavioral parameter sets increased from $90.0 \%$ (a relatively conservative threshold for equifinality quantification) to $97.5 \%$ (a relatively liberal threshold), uncertainty in the GCM ensembles and its relative size to the uncertainty in the parameter ensembles increased exponentially (Figure 12). In the case of SS, parameter selection was more critical than GCM selection in all of the threshold cases. When relatively loose thresholds (i.e., $90.0 \%$ and $92.5 \%$ ) were used, the selection of the hydrologic model parameters became more significant than GCM selection for the GW and PET projections, implying that the selection of hydrologic model parameters needs to be more careful than that for GCMs when soil moisture and groundwater are the concerns of a climate change impact study using the water balance

30 model. Since ET is directly determined based on precipitation and direct runoff in the ABCD model, the corresponding uncertainty would become as significant as the uncertainty in the QQ projections (Figure 12). Overall, and depending on the 
Hydrol. Earth Syst. Sci. Discuss., doi:10.5194/hess-2016-160, 2016

Manuscript under review for journal Hydrol. Earth Syst. Sci.

Published: 7 July 2016

(c) Author(s) 2016. CC-BY 3.0 License.

thresholds, GCM selection was 1.5 to 2 times more influential than parameter selection with respect to an assessment of the climate change impacts on the overall amount of available water in the watersheds.

The contribution of each GCM to the uncertainty in the GCM ensembles varied depending on the types of hydrologic components (Figure 13). Overall, the amounts of uncertainty contained in the climate change projections made by BCC,

5 GCESS, CCCMA, CSIRO-QCCCE, and LASG-CESS for the Ohio River Basin watersheds were larger than those in the projections provided by INM, IPSL, and MIROC. Furthermore, the amount of uncertainty in precipitation projections of some GCMs was large while uncertainty in their temperature projections was small, and vice versa. The uncertainty amounts in the following three GCMs were relatively small for both of the climate variables in the Ohio River watersheds: CMCCCMS, IPSL-CM5A-LR_1, and IPSL-CM5A-LR_4. The amounts of uncertainty in the GCM ensemble projections for the

10 hydrologic components were highly correlated with those of the GCM-ensemble projections for precipitation rather than those for temperature (Figure 14). For example, the amount of uncertainty in the precipitation ensemble was related to those of QQ, DR, GW, and WW with correlation coefficients greater than 0.75 , implying that the uncertainty in the precipitation ensemble was transferred to the hydrologic simulation. This finding also suggested that a greater effort needs to be invested in improving the projection accuracy of precipitation than temperature in a hydrologic analysis of climate change (Figures

15 14). PET was moderately correlated with TMX, TMN, and TAV, and this reflects the characteristics of the Hargreaves equation (Equation (5)) that was used for the PET calculation of this study.

\section{Conclusions}

This study demonstrated that the significance of GCM and hydrological parameter selection varied depending on the hydrologic components of interest and the thresholds used to identify the behavioral parameter sets in a hydrologic analysis

20 of climate change. Streamflow and direct runoff projections were considerably affected by the uncertainty in multi-GCM ensembles, but soil moisture and groundwater projections were more responsive to the uncertainty in multi-parameter ensembles, implying that the selection of both GCMs and parameters should be carefully made to improve the reliability of a climate change impact analysis. The precipitation projection uncertainty was much more closely correlated to the uncertainty of the hydrological projections especially for runoff than that of the temperature projection, suggesting that the reliability of

25 the precipitation projections made by GCMs need to be investigated for a robust hydrologic analysis of climate change. A newly proposed analysis strategy enabled to investigate the contributions of each GCM to uncertainty in a multi-GCM ensemble. Some of the GCMs produced more uncertainty in the hydrologic projections than others, but a corresponding investigation was beyond the scope of this study.

This study was implemented for 61 watersheds in the Ohio River basin to show the variability of the quantified amounts of 30 uncertainty over different watersheds regarding size and location. Although a close relation might also exist between the unique landscape characteristics of the watersheds and the uncertainty amounts in the ensemble predictions, the matter has 
Hydrol. Earth Syst. Sci. Discuss., doi:10.5194/hess-2016-160, 2016

Manuscript under review for journal Hydrol. Earth Syst. Sci.

Published: 7 July 2016

(c) Author(s) 2016. CC-BY 3.0 License.

been left to a future study. A total of $22 \mathrm{GCMs}$ and their variants were considered in this study so that wide ranges of mathematical representations and the simulation strategies of climate change could be considered so that the largest uncertainty in the multi-GCM ensembles could be explored. Uncertainty associated with GCM selection was considerably large and greater than the amount of precipitation, indicating GCM selection is likely to substantially affect a hydrologic

5 analysis of climate change. Such a finding suggested that a map showing the ranges (uncertainty) and trends of the precipitation and temperature projections should be built using multiple GCMs, or hopefully all of them - which are used in the global scale climate projections for watersheds (e.g., 8- or 12-digit Hydrologic Unit Code watersheds) — to guide the field of hydrologic modeling for more effective GCM selection in the climate change studies regarding local watersheds.

\section{References}

10 Akhtar, M., Ahmad, N., and Booij, M.: Use of regional climate model simulations as input for hydrological models for the Hindukush-Karakorum-Himalaya region, Hydrology and Earth System Sciences, 13, 1075-1089, 2009.

Arheimer, B., Andréasson, J., Fogelberg, S., Johnsson, H., Pers, C. B., and Persson, K.: Climate change impact on water quality: model results from southern Sweden, AMBIO: A Journal of the Human Environment, 34, 559-566, 2005.

Arora, V. K., and Boer, G. J.: Effects of simulated climate change on the hydrology of major river basins, Journal of

15 Geophysical Research, 106(D4), 3335-3348, 2001.

Bergstrom, S., Carlsson, B., Gardelin, M., Lindstrom, G., Pettersson, A., and Rummukainen, M.: Climate change impacts on runoff in Sweden-assessments by global climate models, dynamical downscaling and hydrological modelling, Climate research, 16, 101-112, 2001.

Beven, K.: A manifesto for the equifinality thesis, Journal of hydrology, 320, 18-36, 2006.

20 Beven, K., and Freer, J.: Equifinality, data assimilation, and uncertainty estimation in mechanistic modelling of complex environmental systems using the GLUE methodology, Journal of hydrology, 249, 11-29, 2001.

Chen, J., Brissette, F. P., Poulin, A., and Leconte, R.: Overall uncertainty study of the hydrological impacts of climate change for a Canadian watershed, Water Resources Research, 47, 2011.

Chien, H., Yeh, P. J.-F., and Knouft, J. H.: Modeling the potential impacts of climate change on streamflow in agricultural

25 watersheds of the Midwestern United States, Journal of hydrology, 491, 73-88, 2013.

Chong-Hai, X., and Ying, X.: The projection of temperature and precipitation over China under RCP scenarios using a CMIP5 multi-model ensemble, Atmospheric and Oceanic Science Letters, 5, 527-533, 2012.

Christensen, J. H., Boberg, F., Christensen, O. B., and Lucas-Picher, P.: On the need for bias correction of regional climate change projections of temperature and precipitation, Geophysical Research Letters, 35(20), 2008.

30 Christensen, N. S., and Lettenmaier, D. P.: A multimodel ensemble approach to assessment of climate change impacts on the hydrology and water resources of the Colorado River Basin, Hydrology and Earth System Sciences Discussions, 11, 14171434, 2007. 
Hydrol. Earth Syst. Sci. Discuss., doi:10.5194/hess-2016-160, 2016

Manuscript under review for journal Hydrol. Earth Syst. Sci.

Döll, P., and Schmied, H. M.: How is the impact of climate change on river flow regimes related to the impact on mean annual runoff?, A global-scale analysis, Environmental Research Letters, 7, 1-11, 2012.

Diaz-Nieto, J., and Wilby, R. L.: A comparison of statistical downscaling and climate change factor methods: impacts on low flows in the River Thames, United Kingdom, Climatic Change, 69, 245-268, 2005.

5 Dobler, C., Hagemann, S., Wilby, R., and St?ter, J.: Quantifying different sources of uncertainty in hydrological projections in an Alpine watershed, Hydrology and Earth System Sciences, 16, 4343-4360, 2012.

Dooge, J. C.: Sensitivity of runoff to climate change: A Hortonian approach, Bulletin of the American Meteorological Society, 73, 2013-2024, 1992.

Duan, Q., Sorooshian, S., and Gupta, V. K.: Effective and efficient global optimization for conceptual rainfall? runoff

10 models, Water Resources Research, 28(4), 1015-1031, 1992.

Duan, Q., Sorooshian, S., and Gupta, V. K.: Optimal use of the SCE-UA global optimization method for calibrating watershed models, Journal of hydrology, 158(3), 265-284, 1994a.

Ebner, A. D., Koltun, G., and Ostheimer, C. J.: Hydrologic effects of potential changes in climate, water use, and land cover in the Upper Scioto River Basin, Ohio, US Geological Survey, 2328-0328, 2015.

15 Frisbee, M. D., Phillips, F. M., Campbell, A. R., Liu, F., and Sanchez, S. A.: Streamflow generation in a large, alpine watershed in the southern Rocky Mountains of Colorado: Is streamflow generation simply the aggregation of hillslope runoff responses?, Water Resources Research, 47, 2011.

Frisbee, M. D., Phillips, F. M., Weissmann, G. S., Brooks, P. D., Wilson, J. L., Campbell, A. R., and Liu, F.: Unraveling the mysteries of the large watershed black box: Implications for the streamflow response to climate and landscape perturbations,

20 Geophysical Research Letters, 39, 2012.

Fu, G., Charles, S. P., and Chiew, F. H.: A two parameter climate elasticity of streamflow index to assess climate change effects on annual streamflow, Water Resources Research, 43, 2007.

Gosling, S., Taylor, R., Arnell, N., and Todd, M.: A comparative analysis of projected impacts of climate change on river runoff from global and catchment-scale hydrological models, Hydrology and Earth System Sciences, 15, $279-294,2011$.

25 Graham, L. P., Andréasson, J., and Carlsson, B.: Assessing climate change impacts on hydrology from an ensemble of regional climate models, model scales and linking methods-a case study on the Lule River basin, Climatic Change, 81, 293$307,2007$.

Graiprab, P., Pongput, K., Tangtham, N., and Gassman, P. W.: Hydrologic evaluation and effect of climate change on the At Samat watershed, Northeastern Region, Thailand, International Agricultural Engineering Journal, 19, 12-22, 2010.

30 Guo, S., Wang, J., Xiong, L., Ying, A., and Li, D.: A macro-scale and semi-distributed monthly water balance model to predict climate change impacts in China, Journal of hydrology, 268, 1-15, 2002.

Harding, B., Wood, A., and Prairie, J.: The implications of climate change scenario selection for future streamflow projection in the Upper Colorado River Basin, Hydrology and Earth System Sciences, 16, 3989-4007, 2012. 
Hydrol. Earth Syst. Sci. Discuss., doi:10.5194/hess-2016-160, 2016

Manuscript under review for journal Hydrol. Earth Syst. Sci.

Published: 7 July 2016

(c) Author(s) 2016. CC-BY 3.0 License.

Hawkins, E., and Sutton, R.: The potential to narrow uncertainty in regional climate predictions, Bulletin of the American Meteorological Society, 90(8), 1095-1107, 2009.

Hayhoe, K., Wake, C. P., Huntington, T. G., Luo, L., Schwartz, M. D., Sheffield, J., Wood, E., Anderson, B., Bradbury, J., and DeGaetano, A.: Past and future changes in climate and hydrological indicators in the US Northeast, Climate Dynamics, $528,381-407,2007$.

Her, Y., and Chaubey, I.: Impact of the numbers of observations and calibration parameters on equifinality, model performance, and output and parameter uncertainty, Hydrological Processes, 29, 4220-4237, 2015.

Ho, C. K., Stephenson, D. B., Collins, M., Ferro, C. A., and Brown, S. J.: Calibration strategies: a source of additional uncertainty in climate change projections, Bulletin of the American Meteorological Society, 93, 21, 2012.

10 Hostetler, S.: Hydrologic and atmospheric models: the (continuing) problem of discordant scales, Climatic Change, 27, $345-$ $350,1994$.

Huff, D., O'Neill, R., Emanuel, W., Elwood, J., and Newbold, J.: Flow variability and hillslope hydrology, Earth Surface Processes and Landforms, 7, 91-94, 1982.

Hulme, P. E.: Adapting to climate change: is there scope for ecological management in the face of a global threat?, Journal 15 of Applied ecology, 42, 784-794, 2005.

Johnson, C. R., Banks, S. C., Barrett, N. S., Cazassus, F., Dunstan, P. K., Edgar, G. J., Frusher, S. D., Gardner, C., Haddon, M., and Helidoniotis, F.: Climate change cascades: Shifts in oceanography, species' ranges and subtidal marine community dynamics in eastern Tasmania, Journal of Experimental Marine Biology and Ecology, 400, 17-32, 2011.

Kay, A., Davies, H., Bell, V., and Jones, R.: Comparison of uncertainty sources for climate change impacts: flood frequency 20 in England, Climatic Change, 92, 41-63, 2009.

Knutti, R., Furrer, R., Tebaldi, C., Cermak, J., and Meehl, G. A.: Challenges in combining projections from multiple climate models, Journal of Climate, 23, 2739-2758, 2010.

Kunkel, K. E.: Regional climate trends and scenarios for the US national climate assessment, US Department of Commerce, National Oceanic and Atmospheric Administration, National Environmental Satellite, Data, and Information Service, 2013.

25 Kunkel, K.E., Stevens, L.E., Stevens, S.E., Sun, L., Janssen, E., Wuebbles, D., Kruk, M.C., Thomas, D.P., Shulski, M.D., Umphlett, N. and Hubbard, K.G.: Regional climate trends and scenarios for the US national climate assessment. Part 3. Climate of the Midwest U.S. NOAA technical report NESDIS, 142(3), 2013.

Liew, M. W. V., Feng, S., and Pathak, T.: Climate change impacts on streamflow, water quality, and best management practices for the Shell and Logan Creek Watersheds in Nebraska, USA, International Journal of Agricultural and Biological

30 Engineering, 5, 13-34, 2012.

Liu, Q., and Cui, B.: Impacts of climate change/variability on the streamflow in the Yellow River Basin, China, Ecological Modelling, 222, 268-274, 2011. 
Hydrol. Earth Syst. Sci. Discuss., doi:10.5194/hess-2016-160, 2016

Manuscript under review for journal Hydrol. Earth Syst. Sci.

Published: 7 July 2016

(c) Author(s) 2016. CC-BY 3.0 License.

Lopez, A., Fung, F., New, M., Watts, G., Weston, A., and Wilby, R. L.: From climate model ensembles to climate change impacts and adaptation: A case study of water resource management in the southwest of England, Water Resources Research, 45, 2009.

Lui, Q. and Yang Z.: Quantitative estimation of the impact of climate change on actual evapotranspiration in the Yellow

5 River Basin, China. Journal of Hydrology, 395, 226-234, 2010.

Mango, L.M., Melesse, A.M., McClain, M.E., Gann, D., and Setegn, S.G.: Land use and climate change impacts on the hydrology of the upper Mara River Basin, Kenya: results of a modeling study to support better resource management, Hydrology and Earth System Science 15, 2245-2258, 2011.

Maraun, D.: Bias correction, quantile mapping, and downscaling: Revisiting the inflation issue, Journal of Climate, 26,

$10 \quad 2137-2143,2013$.

Maurer, E. P., Brekke, L. D., and Pruitt, T.: Contrasting Lumped and Distributed Hydrology Models for Estimating Climate Change Impacts on California Watersheds1, in, Wiley Online Library, 2010.

Mearns, L., and Arnold, J.: Impacts of climate change on Missouri River Basin water yield, Journal of the American Water Resources Association, 37, 1119-1129, 2001.

15 Meyer, J. L., Strayer, D. L., Wallace, J. B., Eggert, S. L., Helfman, G. S., and Leonard, N. E.: The contribution of headwater streams to biodiversity in river networks1, in, Wiley Online Library, 2007.

Murphy, J. M., Sexton, D. M., Barnett, D. N., Jones, G. S., Webb, M. J., Collins, M., and Stain forth, D. A.: Quantification of modelling uncertainties in a large ensemble of climate change simulations, Nature, 430, 768-772, 2004.

Najafi, M., Moradkhani, H., and Jung, I.: Assessing the uncertainties of hydrologic model selection in climate change impact

20 studies, Hydrological Processes, 25, 2814-2826, 2011.

Nohara, D., Kitoh, A., Hosaka, M., and Oki, T.: Impact of climate change on river discharge projected by multi model ensemble, Journal of Hydrometeorology, 7, 1076-1089, 2006.

Oubeidillah, A. A., Kao, S.-C., Ashfaq, M., Naz, B. S., and Tootle, G.: A large-scale, high-resolution hydrological model parameter data set for climate change impact assessment for the conterminous US, Hydrology and Earth System Sciences, 18,

$25 \quad 67-84,2014$.

Overland, J. E., Wang, M., Bond, N. A., Walsh, J. E., Kattsov, V. M., and Chapman, W. L.: Considerations in the selection of global climate models for regional climate projections: the Arctic as a case study*, Journal of Climate, 24, 1583-1597, 2011.

Panagopoulos, Y., Gassman, P. W., Arritt, R. W., Herzmann, D. E., Campbell, T. D., Valcu, A., Jha, M. K., Kling, C. L.,

30 Srinivasan, R., and White, M.: Impacts of climate change on hydrology, water quality and crop productivity in the OhioTennessee River Basin, International Journal of Agricultural and Biological Engineering, 8, 36, 2015.

Parker, W. S.: Predicting weather and climate: Uncertainty, ensembles and probability, Studies in History and Philosophy of Science Part B: Studies in History and Philosophy of Modern Physics, 41, 263-272, 2010. 
Hydrol. Earth Syst. Sci. Discuss., doi:10.5194/hess-2016-160, 2016

Manuscript under review for journal Hydrol. Earth Syst. Sci.

Published: 7 July 2016

(c) Author(s) 2016. CC-BY 3.0 License.

Pierce, D. W., Barnett, T. P., Santer, B. D., and Gleckler, P. J.: Selecting global climate models for regional climate change studies, Proceedings of the National Academy of Sciences, 106, 8441-8446, 2009.

Poff, N.L., Tokar, S., and Johnson, P.: Stream hydrological and ecological responses to climate change assessed with an artificial neural network, Limnology and Oceanography, 41(5), 857-863, 1996.

5 Poulin, A., Brissette, F., Leconte, R., Arsenault, R., and Malo, J.-S.: Uncertainty of hydrological modelling in climate change impact studies in a Canadian, snow-dominated river basin, Journal of hydrology, 409, 626-636, 2011.

Richardson, J. S., and Danehy, R. J.: A synthesis of the ecology of headwater streams and their riparian zones in temperate forests, Forest Science, 53, 131-147, 2007.

Sadegh, M., and Vrugt, J.: Bridging the gap between GLUE and formal statistical approaches: approximate Bayesian 10 computation, Hydrology and Earth System Sciences, 17, 2013.

Sankarasubramanian, A., and Vogel, R. M.: Annual hydroclimatology of the United States, Water Resources Research, 38, 2002.

Sansom, P. G., Stephenson, D. B., Ferro, C. A., Zappa, G., and Shaffrey, L.: Simple uncertainty frameworks for selecting weighting schemes and interpreting multimodel ensemble climate change experiments, Journal of Climate, 26, 4017-4037, 2013.

Sheshukov, A. Y., Siebenmorgen, C. B., and Douglas-Mankin, K. R.: Seasonal and annual impacts of climate change on watershed response using an ensemble of global climate models, Transactions of the ASABE, 54, 2209-2218, 2011.

Stanfield, L. W., and Jackson, D. A.: Understanding the Factors That Influence Headwater Stream Flows in Response to Storm Events1, in, Wiley Online Library, 2011.

20 Stocker, T., Qin, D., Plattner, G., Tignor, M., Allen, S., Boschung, J., Nauels, A., Xia, Y., Bex, V., and Midgley, P.: Climate Change 2013: The physical basis. Contribution of Working Group I to the Fifth Assessment Report of the Intergovernmental Panel on Climate Change, in, Cambridge University Press, Cambridge, UK, 2013.

Stone, M. C., Hotchkiss, R. H., and Mearns, L. O.: Water yield responses to high and low spatial resolution climate change scenarios in the Missouri River Basin, Geophysical Research Letters, 30, 2003.

25 Taylor, K. E., Stouffer, R. J., and Meehl, G. A.: An overview of CMIP5 and the experiment design, Bulletin of the American Meteorological Society, 93, 485-498, 2012.

Tebaldi, C., and Knutti, R.: The use of the multi-model ensemble in probabilistic climate projections, Philosophical Transactions of the Royal Society of London A: Mathematical, Physical and Engineering Sciences, 365, $2053-2075,2007$.

Thomas, H.: Improved methods for national water assessment, Report WR15249270, US Water Resource Council, 30 Washington, DC, 1981.

Tigkas, D., Vangelis, H., and Tsakiris, G.: Drought and climatic change impact on streamflow in small watersheds, Science of the total environment, 440, 33-41, 2012.

Van der Linden, P., and Mitchell, J., editors: ENSEMBLES: Climate Change and its Impacts: Summary of research and results from the ENSEMBLES project, Met Office Hadley Centre, FitzRoy Road, Exeter EX1 3PB, UK, $160,2009$. 
Hydrol. Earth Syst. Sci. Discuss., doi:10.5194/hess-2016-160, 2016

Manuscript under review for journal Hydrol. Earth Syst. Sci.

Published: 7 July 2016

(c) Author(s) 2016. CC-BY 3.0 License.

(c) (i)

Van Vuuren, D. P., Edmonds, J., Kainuma, M., Riahi, K., Thomson, A., Hibbard, K., Hurtt, G. C., Kram, T., Krey, V., and Lamarque, J.-F.: The representative concentration pathways: an overview, Climatic Change, 109, 5-31, 2011.

Varis, O., Kajander, T., and Lemmel?, R.: Climate and water: from climate models to water resources management and vice versa, Climatic Change, 66, 321-344, 2004.

5 Velázquez, J., Schmid, J., Ricard, S., Muerth, M., Gauvin St-Denis, B., Minville, M., Chaumont, D., Caya, D., Ludwig, R., and Turcotte, R.: An ensemble approach to assess hydrological models' contribution to uncertainties in the analysis of climate change impact on water resources, HESSD, 9, 7441-7474, 2012.

Ward, R.C.: Response to Precipitation of Headwater Streams in Humid Areas, Journal of Hydrology, 74, 171-189, 1984.

Xu, C.-y.: From GCMs to river flow: a review of downscaling methods and hydrologic modelling approaches, Progress in

10 Physical Geography, 23, 229-249, 1999a.

Xu, C.-y.: Climate change and hydrologic models: A review of existing gaps and recent research developments, Water Resources Management, 13, 369-382, 1999b.

Young, C. A., Escobar-Arias, M. I., Fernandes, M., Joyce, B., Kiparsky, M., Mount, J. F., Mehta, V. K., Purkey, D., Viers, J. H., and Yates, D.: Modeling the hydrology of climate change in California's Sierra Nevada for subwatershed scale 15 adaptation1, in, Wiley Online Library, 2009. 
Hydrol. Earth Syst. Sci. Discuss., doi:10.5194/hess-2016-160, 2016

Manuscript under review for journal Hydrol. Earth Syst. Sci.

Published: 7 July 2016

(c) Author(s) 2016. CC-BY 3.0 License.

Hydrology and

(a)

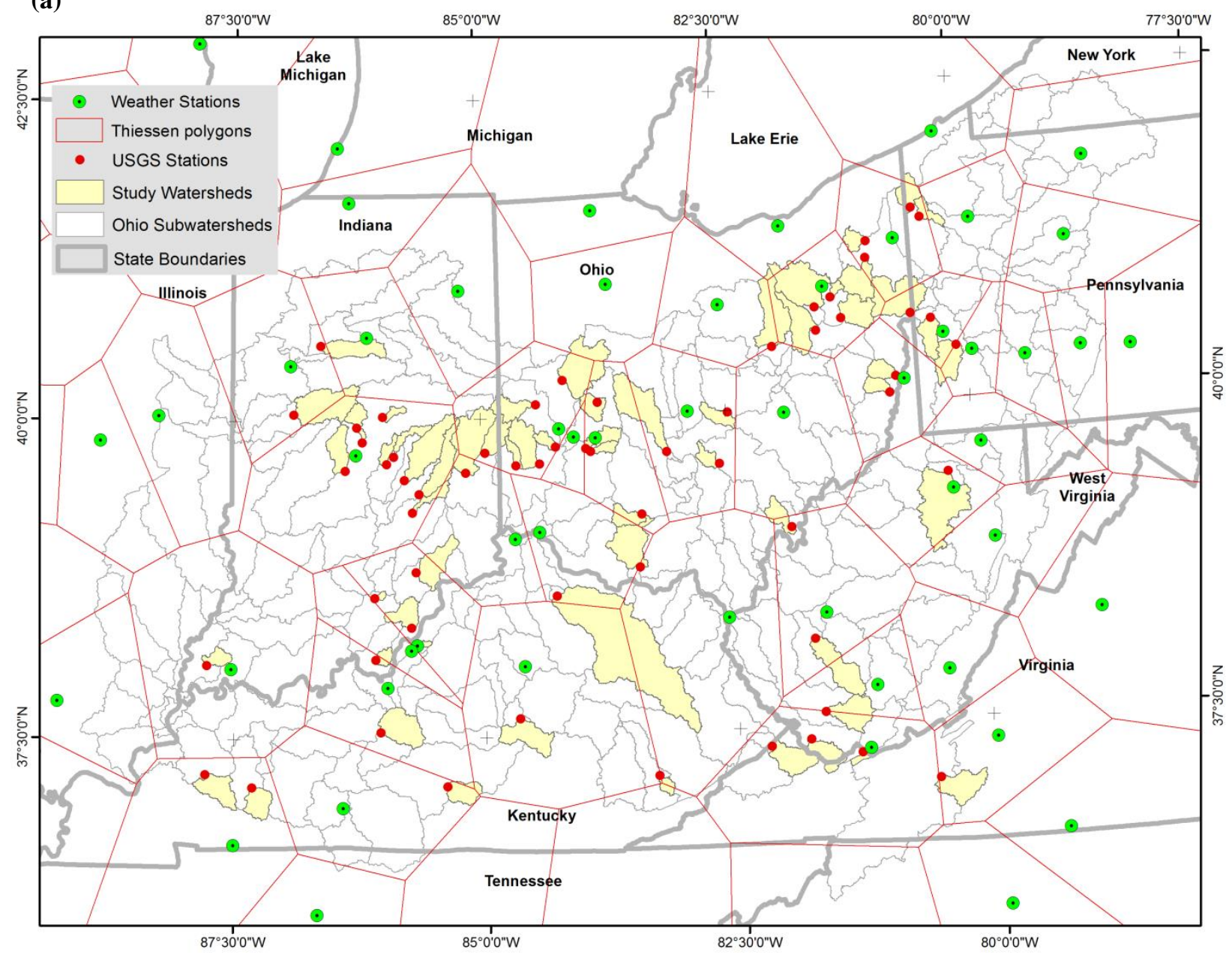


Hydrol. Earth Syst. Sci. Discuss., doi:10.5194/hess-2016-160, 2016

Manuscript under review for journal Hydrol. Earth Syst. Sci.

Published: 7 July 2016

(c) Author(s) 2016. CC-BY 3.0 License.

(c) (i)

(b)

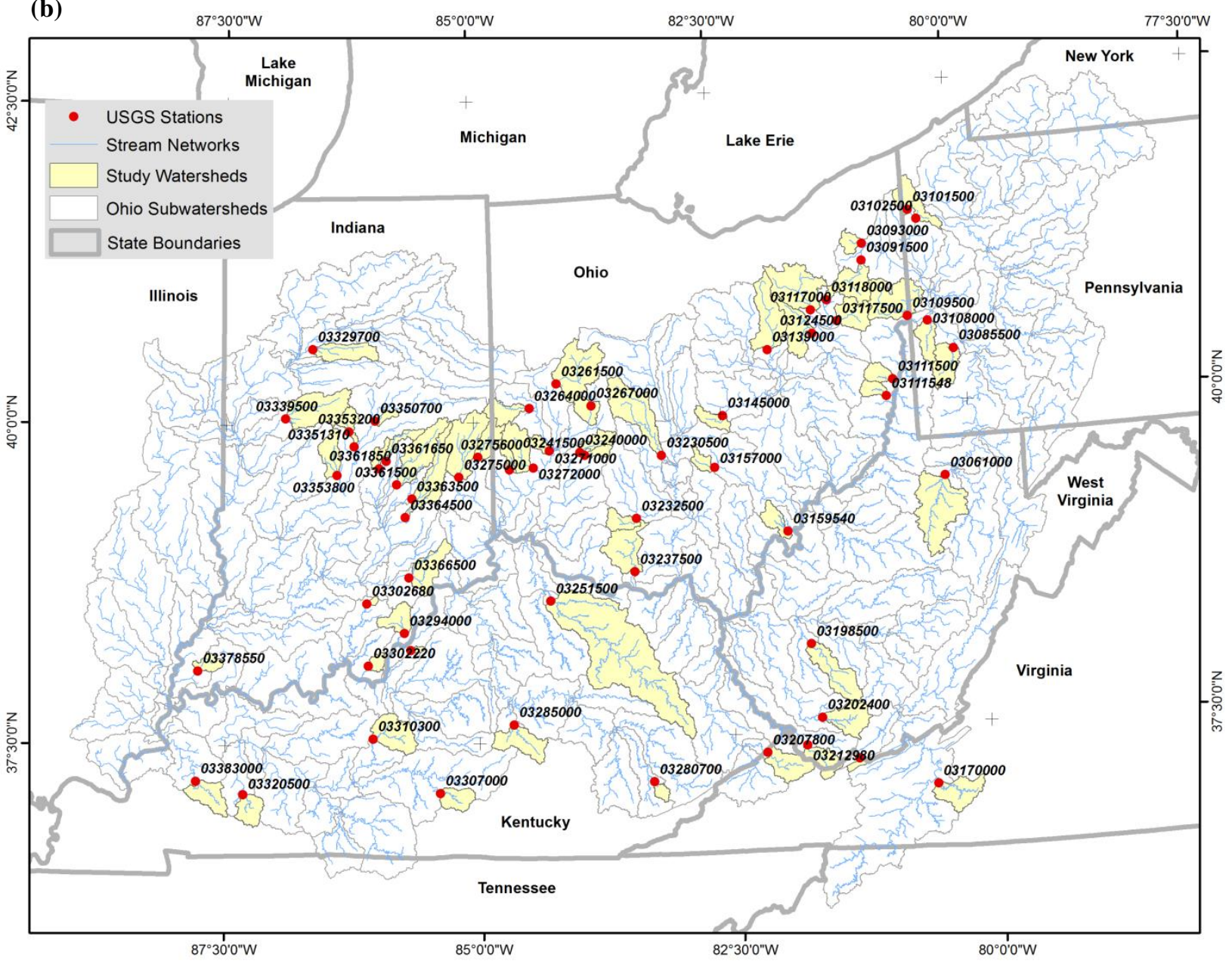


Hydrol. Earth Syst. Sci. Discuss., doi:10.5194/hess-2016-160, 2016

Manuscript under review for journal Hydrol. Earth Syst. Sci.

Published: 7 July 2016

(c) Author(s) 2016. CC-BY 3.0 License.

(c) (i)

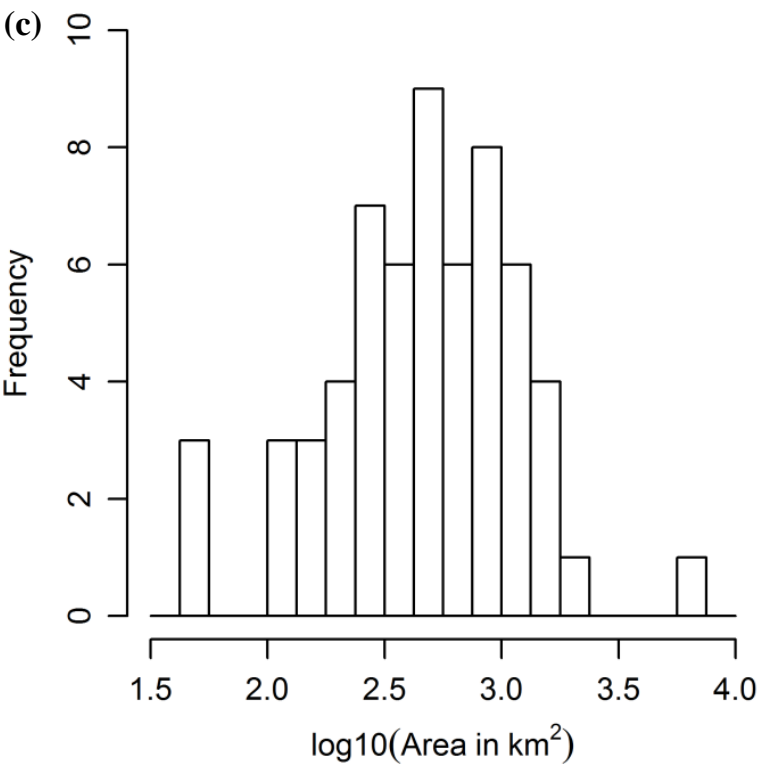

Figure 1: Study watersheds in the Ohio River basin: (a) weather stations into which GCM data were downscaled and their Thiessen polygons, (b) stream networks and USGS gage stations where the ABCD model parameter was calibrated, and (c) variations in the sizes of the study watersheds selected for this study. 
Hydrol. Earth Syst. Sci. Discuss., doi:10.5194/hess-2016-160, 2016

Manuscript under review for journal Hydrol. Earth Syst. Sci.

Published: 7 July 2016

(c) Author(s) 2016. CC-BY 3.0 License.

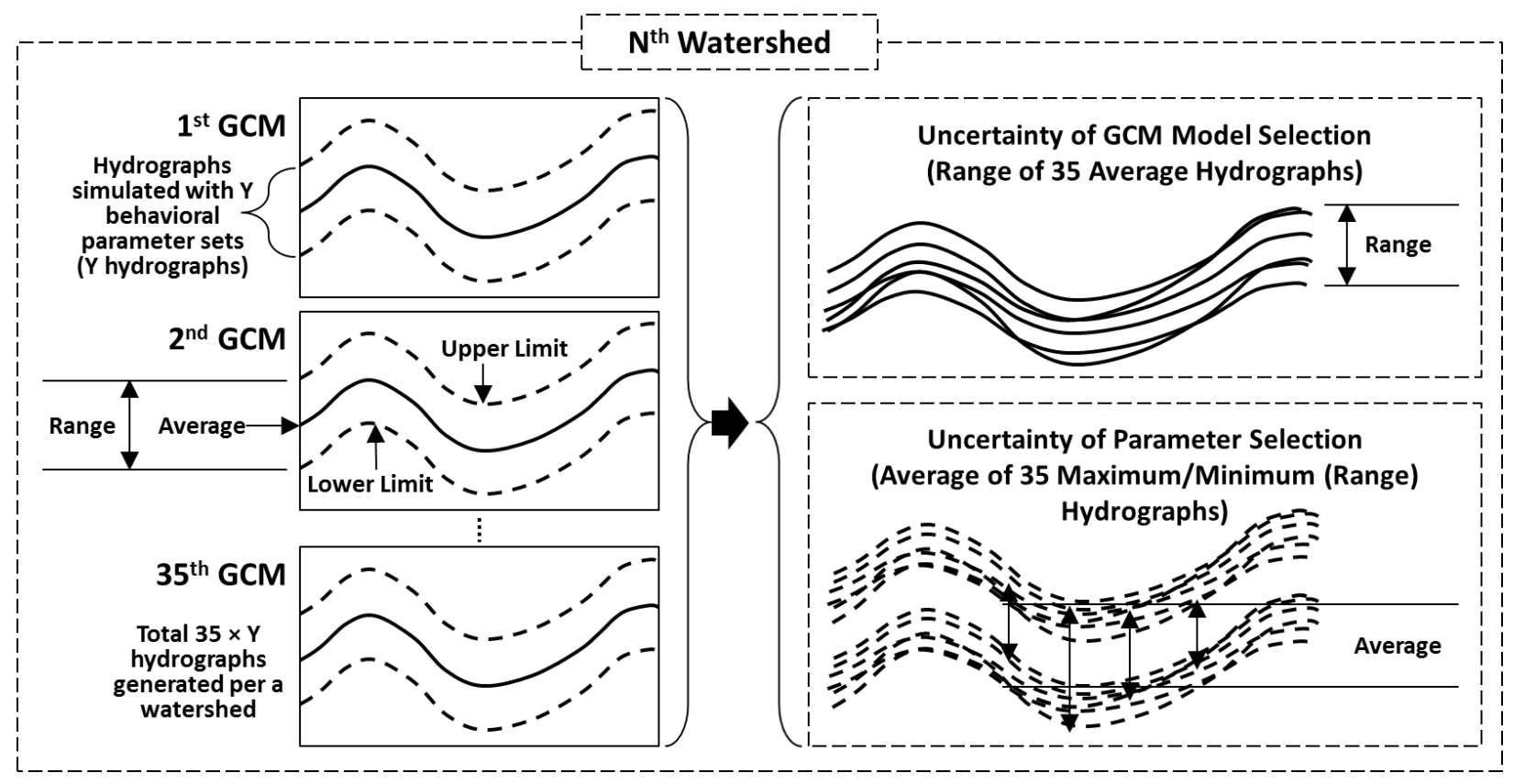

Figure 2. Processes for the quantification of the uncertainty amounts in multi-GCM and multi-parameter ensembles. $N$ varies from 1 to 61, i.e., the number of the Ohio River watersheds selected for this study; $Y$ represents the number of behavioral parameter sets identified for each watershed and therefore varies by the watershed. 
Hydrol. Earth Syst. Sci. Discuss., doi:10.5194/hess-2016-160, 2016

Manuscript under review for journal Hydrol. Earth Syst. Sci.

Published: 7 July 2016

(c) Author(s) 2016. CC-BY 3.0 License.
Hydrology and

Earth System

Sciences

Discussions

(c) (1)
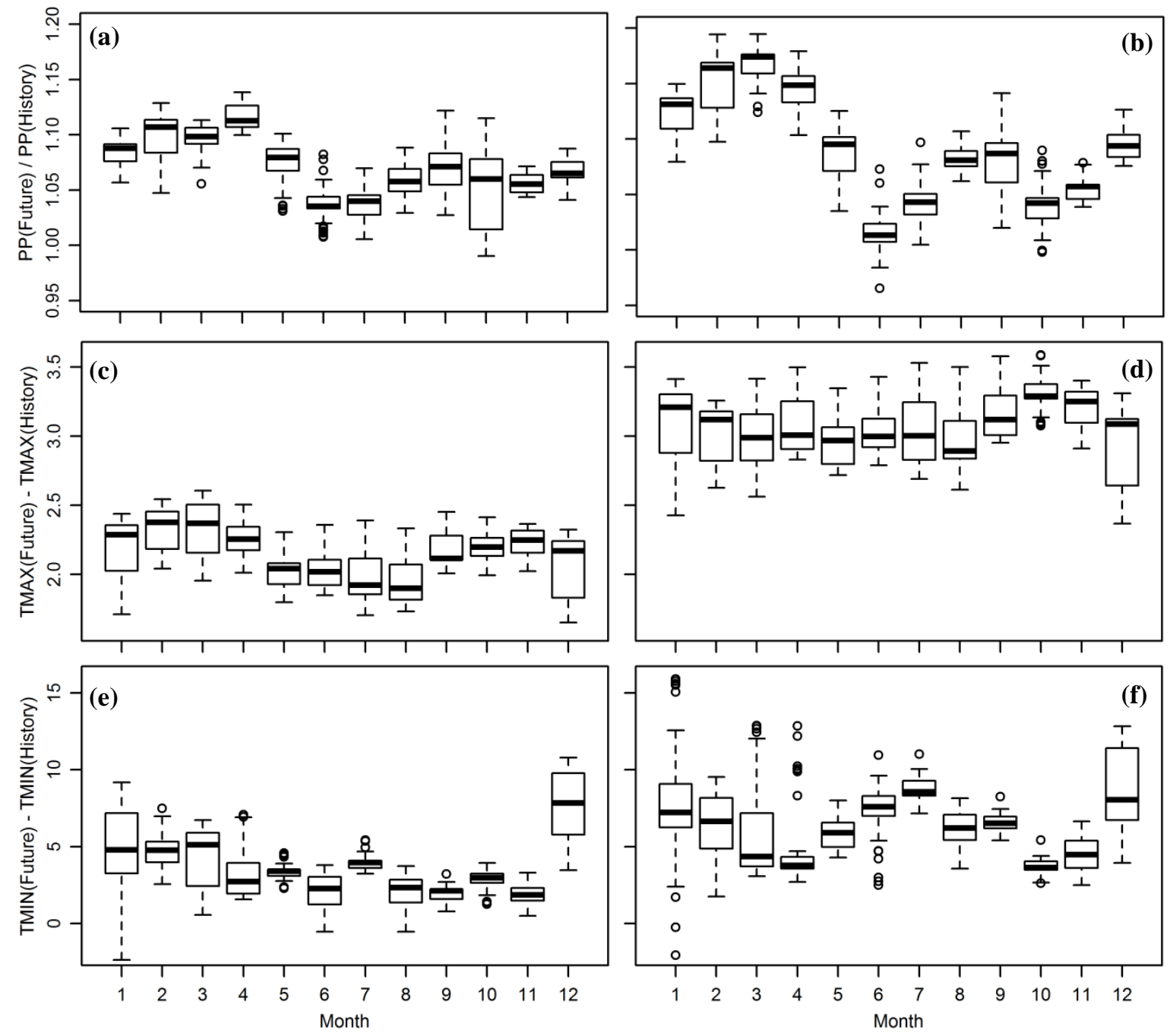

Figure 3: Overall monthly variations of the projected changes of precipitation (projected/historical) and temperature 5 (projected/historical) across all of the study watersheds. a) and b): precipitation; c) and d): maximum temperature; e) and f): minimum temperature; a), c), and d): $\operatorname{RCP} 4.5$; b), d), and f): RCP 8.5. 
Hydrol. Earth Syst. Sci. Discuss., doi:10.5194/hess-2016-160, 2016

Manuscript under review for journal Hydrol. Earth Syst. Sci.

Published: 7 July 2016

(c) Author(s) 2016. CC-BY 3.0 License.
Hydrology and Earth System

Sciences

Discussions
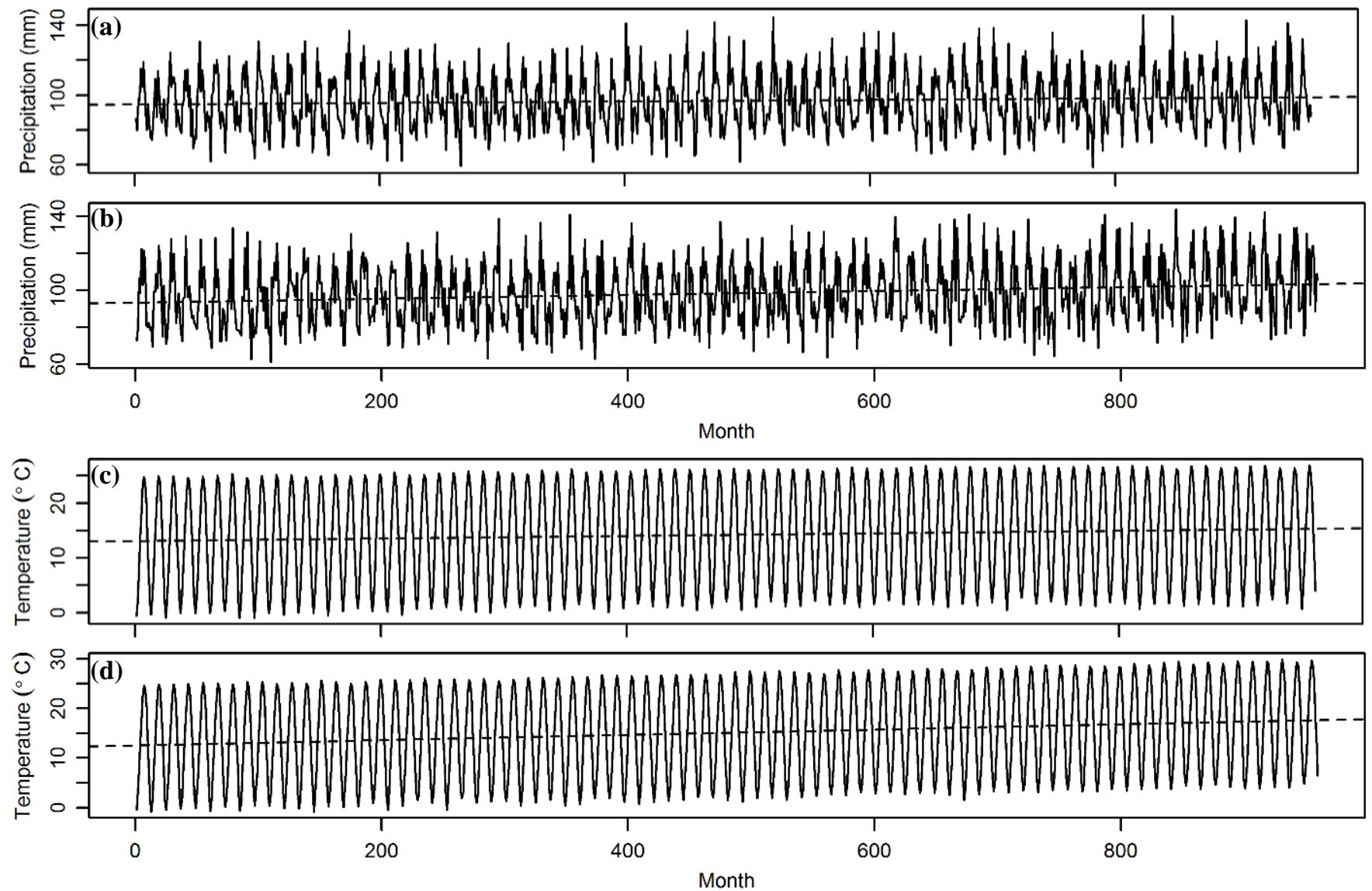

Figure 4: Multi-GCM, multi-parameter, and multi-watershed ensemble projections of the overall average precipitation and temperature of the Ohio River watersheds selected for this study from 2020 to 2099 (960 months). (a) and (c): RCP 4.5; and (b) and (d): RCP 8.5. 
Hydrol. Earth Syst. Sci. Discuss., doi:10.5194/hess-2016-160, 2016

Hydrology and Manuscript under review for journal Hydrol. Earth Syst. Sci.

हิ $:-(a)$

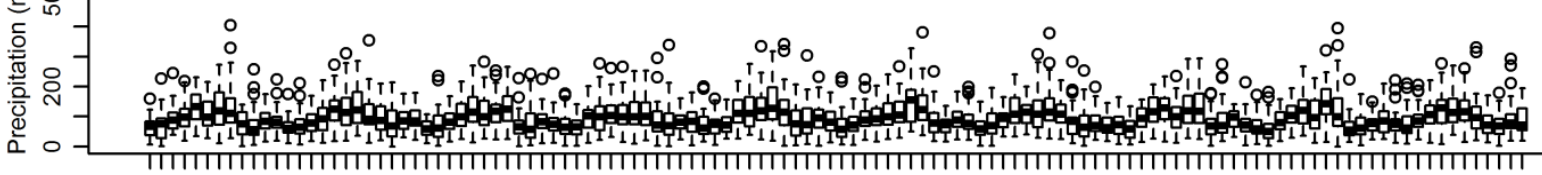

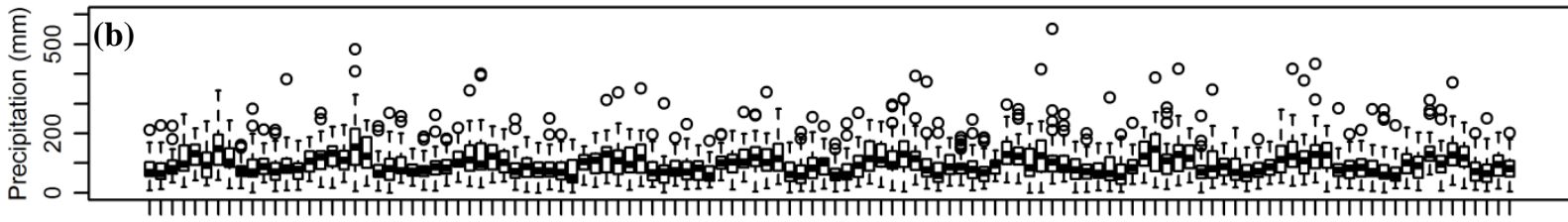

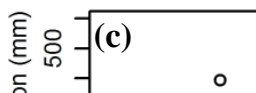

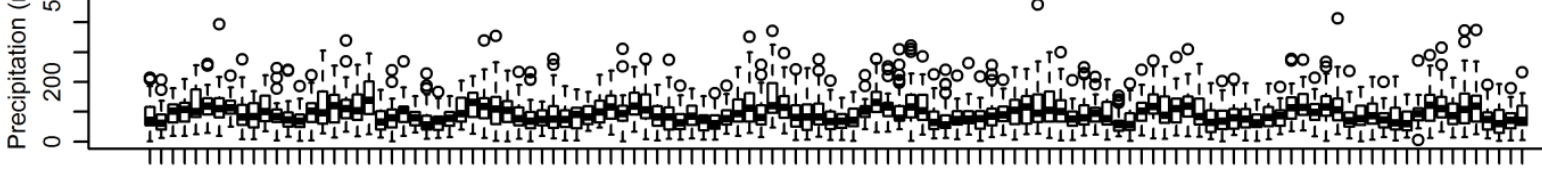

害 品-(d)

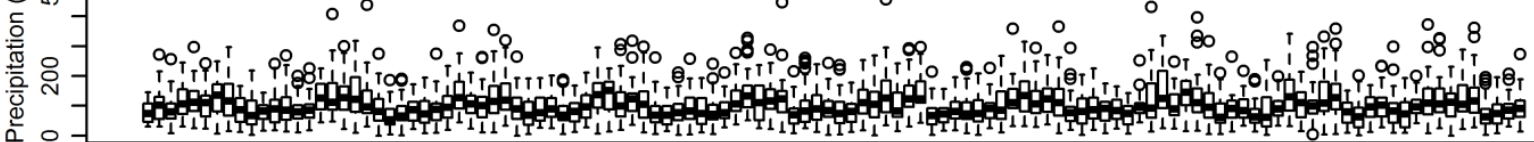

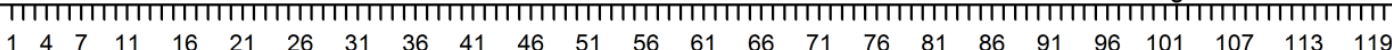
Month
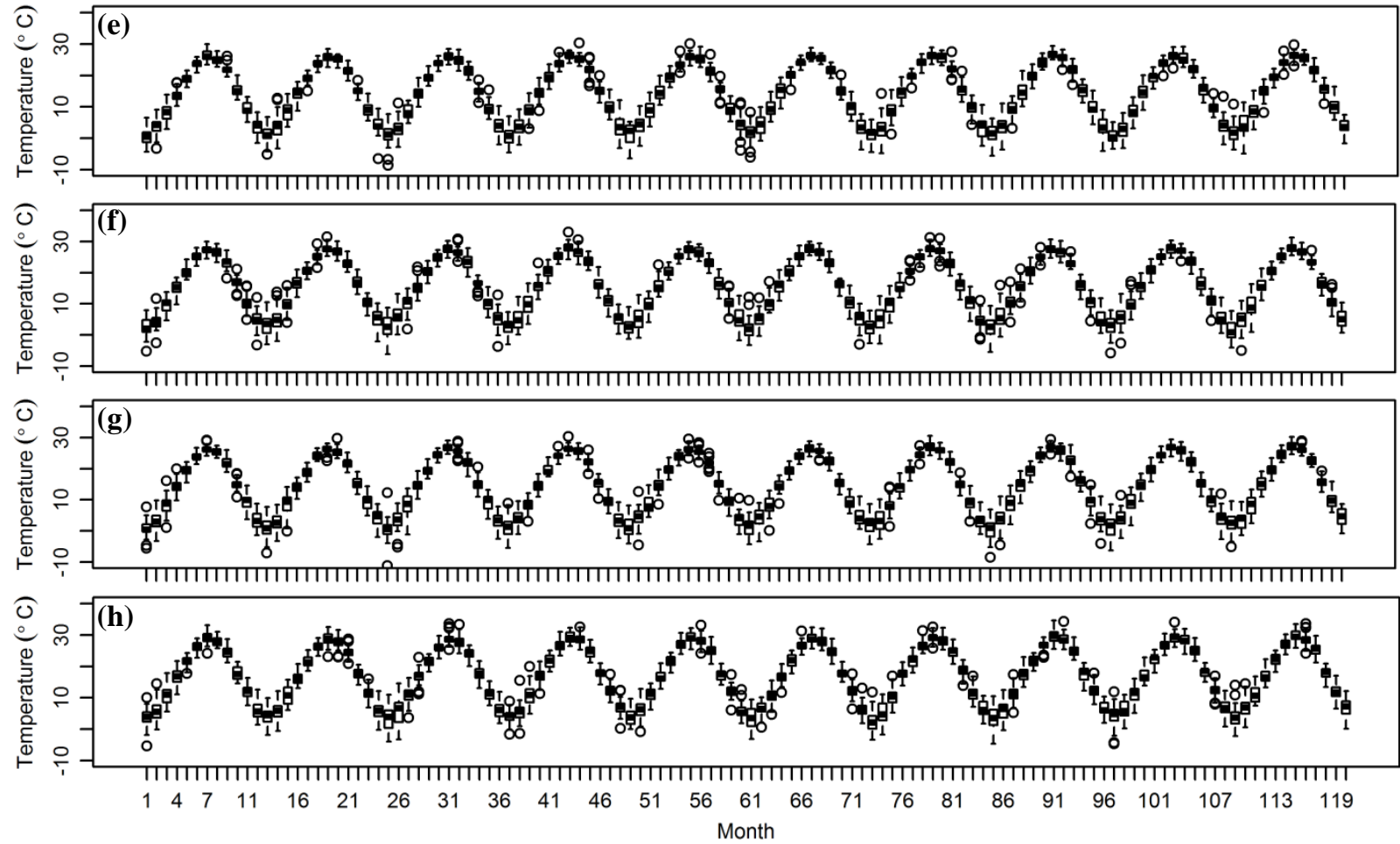
Hydrol. Earth Syst. Sci. Discuss., doi:10.5194/hess-2016-160, 2016

Manuscript under review for journal Hydrol. Earth Syst. Sci.

Published: 7 July 2016

(c) Author(s) 2016. CC-BY 3.0 License.

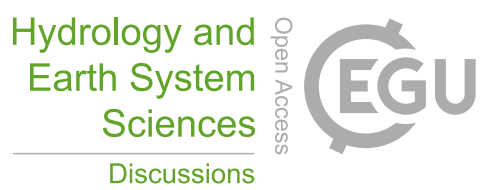

(c) (i)

Figure 5: Monthly variations of the precipitation and temperature projected by the 35 GCMs for the " 03232500 " watershed. (a) and (e) near-future from 2030 to 2039 (120 months) under RCP 4.5; (b) and (f) far-future from 2070 to 2079 (120 months) under RCP 4.5; (c) and (g) near-future from 2030 to 2039 under RCP 8.5; and (d) and (h) far-future from 2070 to 2079 under RCP 8.5. 
Hydrol. Earth Syst. Sci. Discuss., doi:10.5194/hess-2016-160, 2016

Hydrology and Manuscript under review for journal Hydrol. Earth Syst. Sci.

Published: 7 July 2016

(c) $\underset{\mathrm{Br}}{\mathrm{B}}$
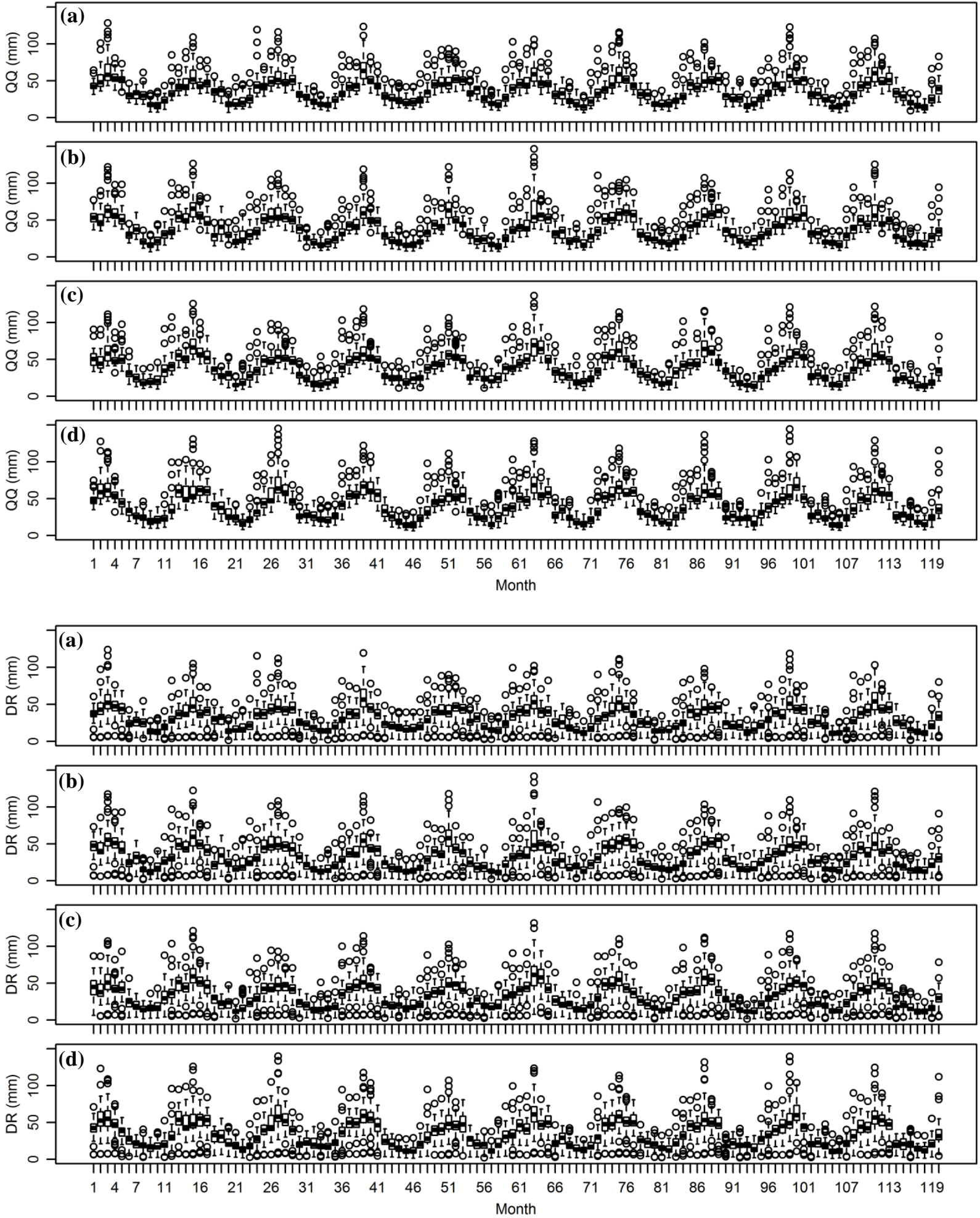
Hydrol. Earth Syst. Sci. Discuss., doi:10.5194/hess-2016-160, 2016

Hydrology and Manuscript under review for journal Hydrol. Earth Syst. Sci.

(c) $\underset{\mathrm{Br}}{\mathrm{B}}$

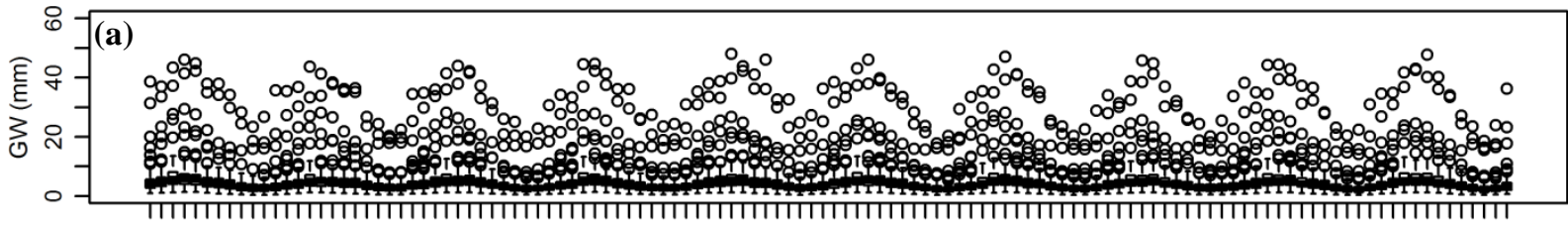

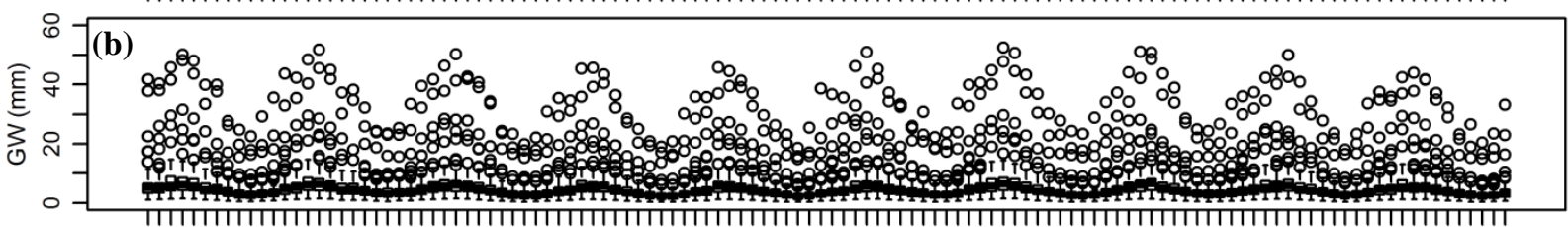

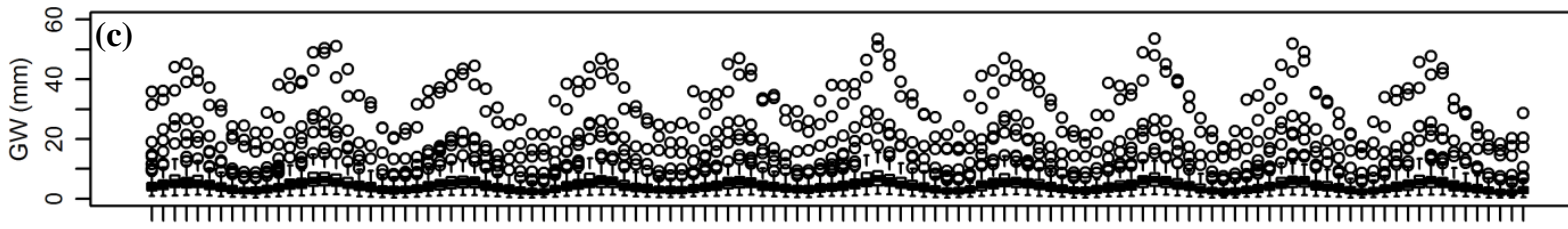
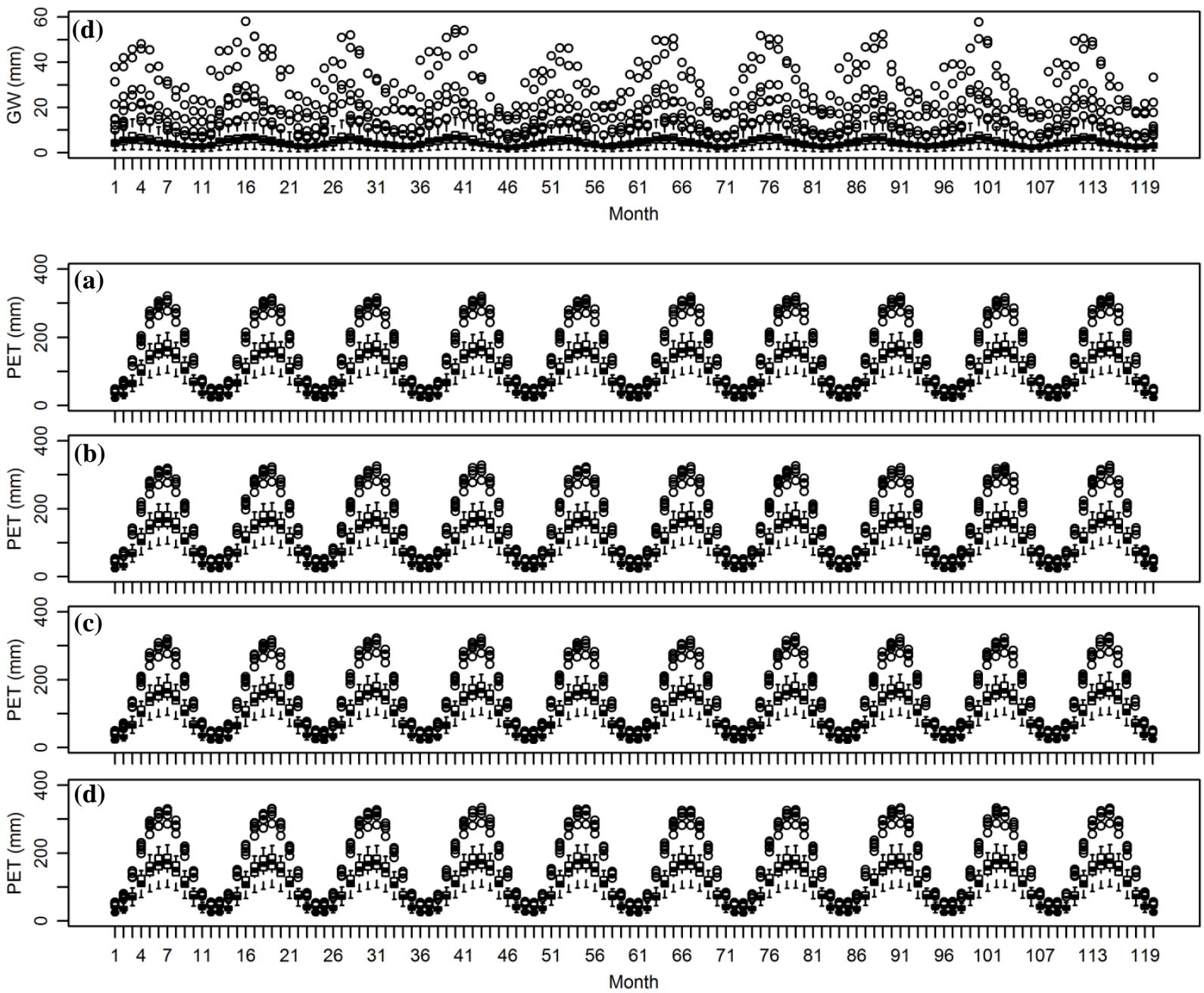
Hydrol. Earth Syst. Sci. Discuss., doi:10.5194/hess-2016-160, 2016
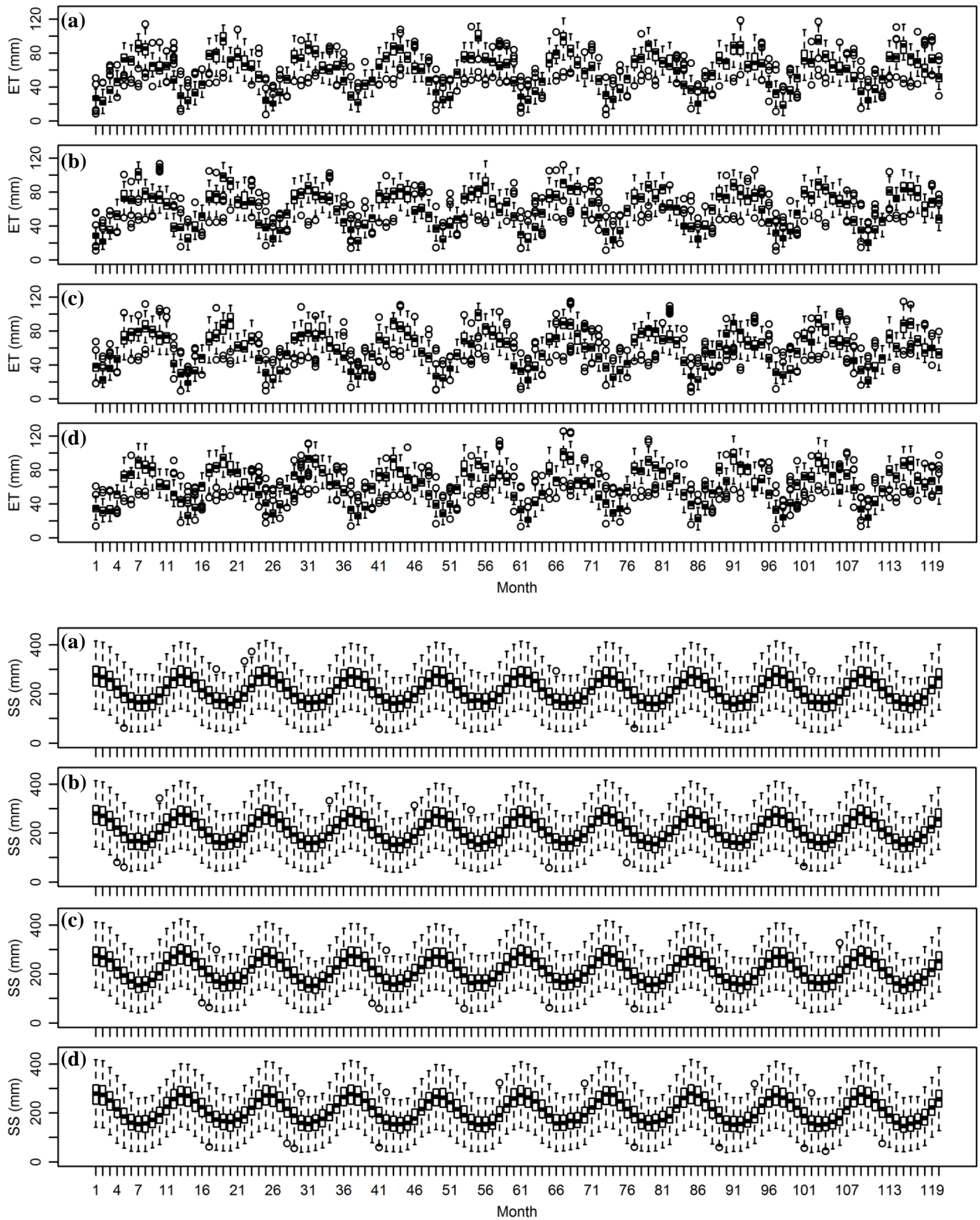
Hydrol. Earth Syst. Sci. Discuss., doi:10.5194/hess-2016-160, 2016

Manuscript under review for journal Hydrol. Earth Syst. Sci.

Published: 7 July 2016
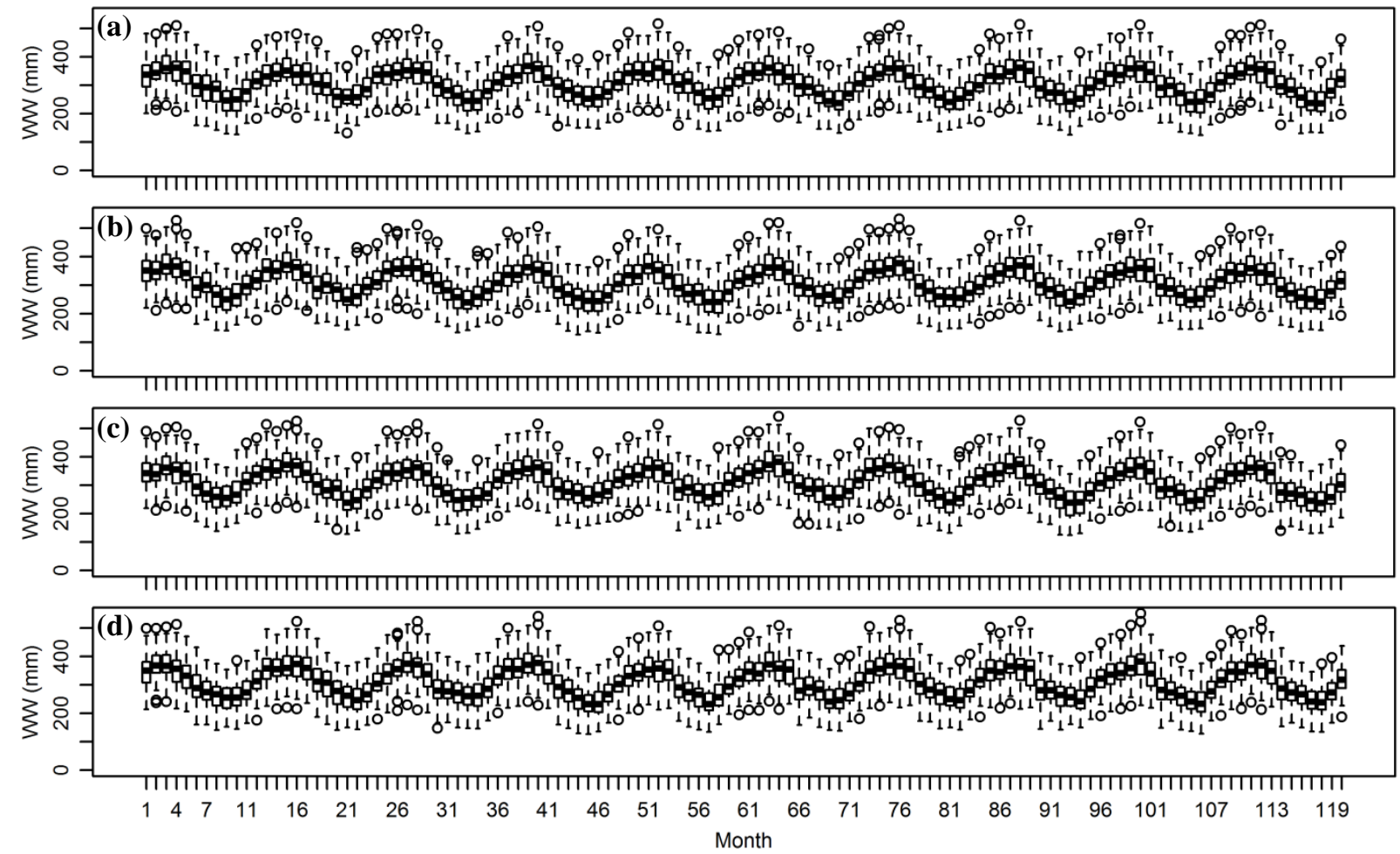

5 Figure 6: Multi-parameter and multi-model ensemble projections for the hydrologic components (QQ, DR, GW, PET, ET, SS and WW) of the 61 Ohio Basin watersheds for the near-future (2030 to 2039, 120 months) and far-future (2070 to 2079,120 months) periods under the RCP 4.5 and RCP 8.5 scenarios. For each hydrologic component, (a) and (b): near-future; (c) and (d): far-future; (a) and (c): RCP 4.5; and (b) and (d): RCP 8.5. 
Hydrol. Earth Syst. Sci. Discuss., doi:10.5194/hess-2016-160, 2016 Manuscript under review for journal Hydrol. Earth Syst. Sci.

Published: 7 July 2016

(c) Author(s) 2016. CC-BY 3.0 License.
Hydrology and

Earth System

Sciences

Discussions

(c) (i)

(a)

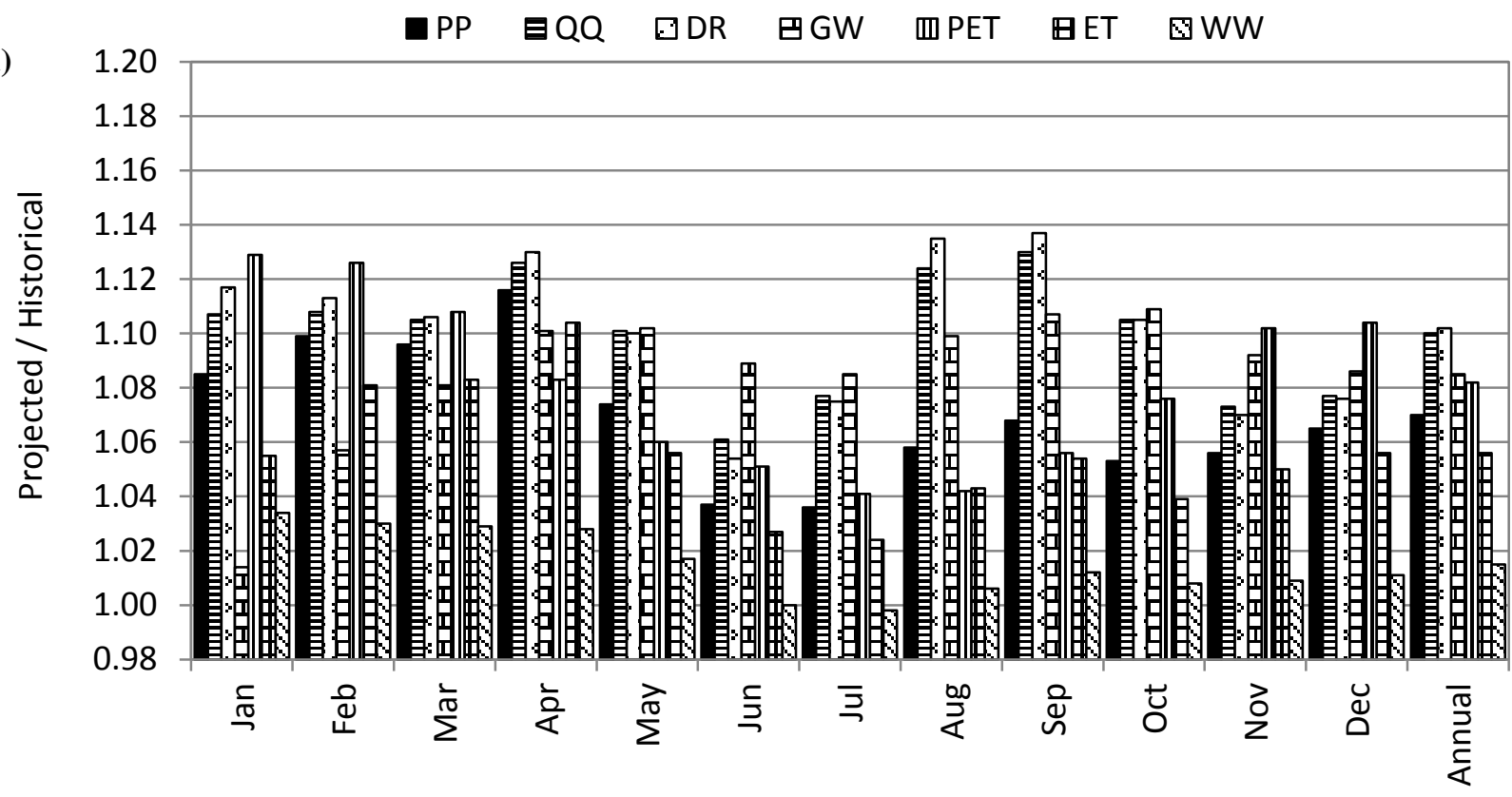

(b)

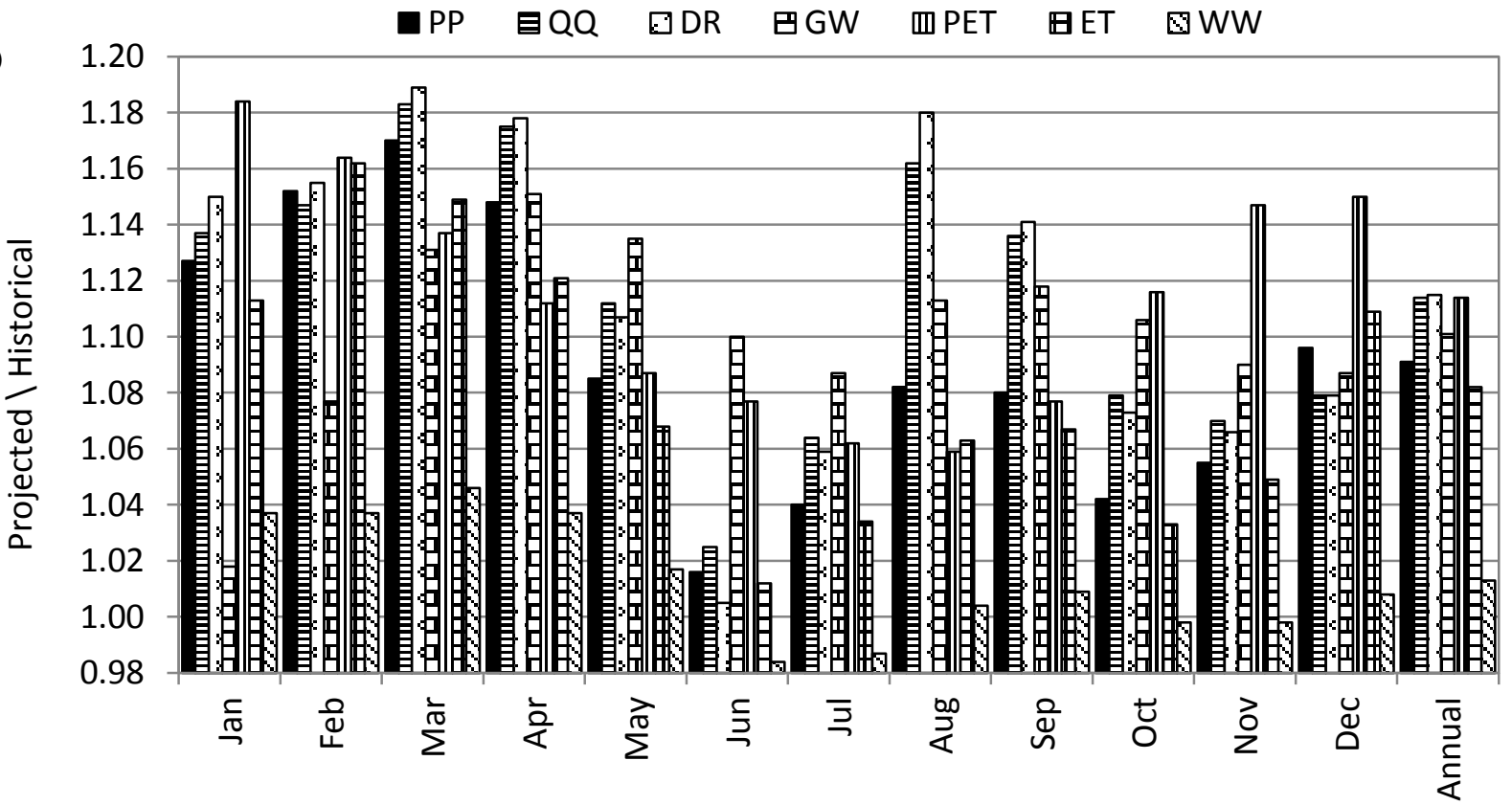

Figure 7: Multi-GCM, multi-parameter, and multi-watershed projections of the overall changes of the hydrologic components of

the study watersheds: (a) RCP 4.5 and (b) RCP 8.5. 
Hydrol. Earth Syst. Sci. Discuss., doi:10.5194/hess-2016-160, 2016

Manuscript under review for journal Hydrol. Earth Syst. Sci.

Published: 7 July 2016

(c) Author(s) 2016. CC-BY 3.0 License.

(c) (1)
Hydrology and

Earth System

Sciences

Discussions
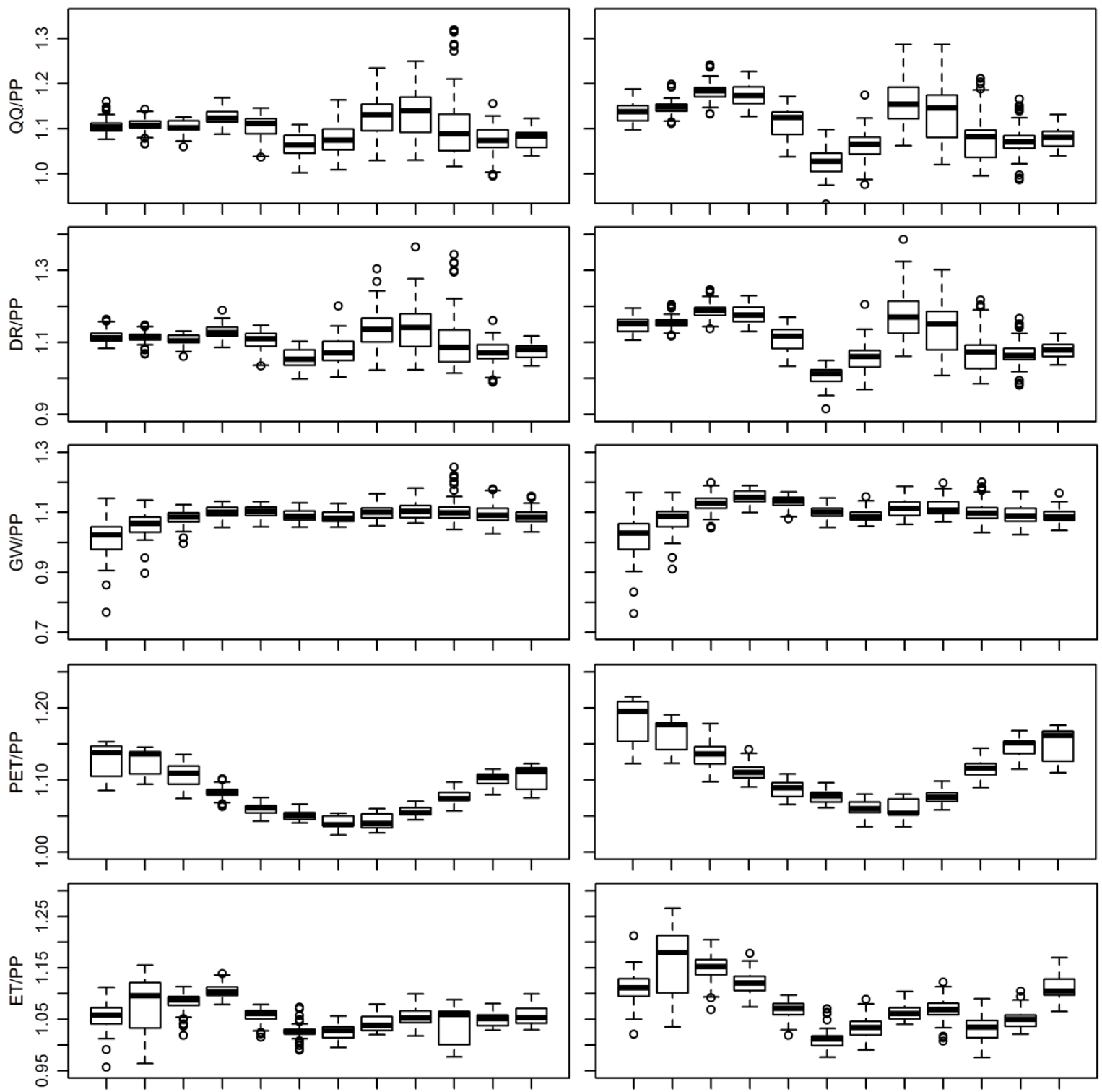
Hydrol. Earth Syst. Sci. Discuss., doi:10.5194/hess-2016-160, 2016

Manuscript under review for journal Hydrol. Earth Syst. Sci.
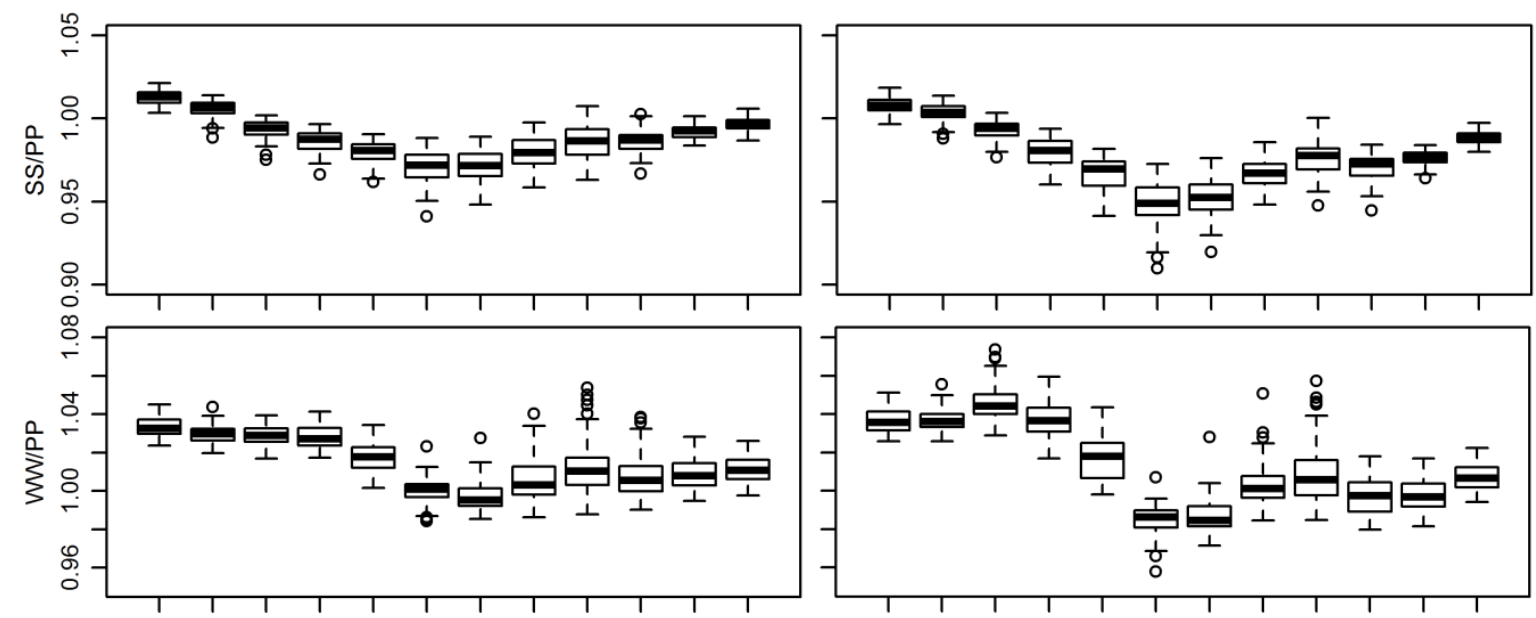

Figure 8: Multi-GCM and multi-parameter ensemble predictions of the changes of the hydrologic components of the watersheds. 
Hydrol. Earth Syst. Sci. Discuss., doi:10.5194/hess-2016-160, 2016

Manuscript under review for journal Hydrol. Earth Syst. Sci.

Published: 7 July 2016

(c) Author(s) 2016. CC-BY 3.0 License.

\section{(c) (1)}
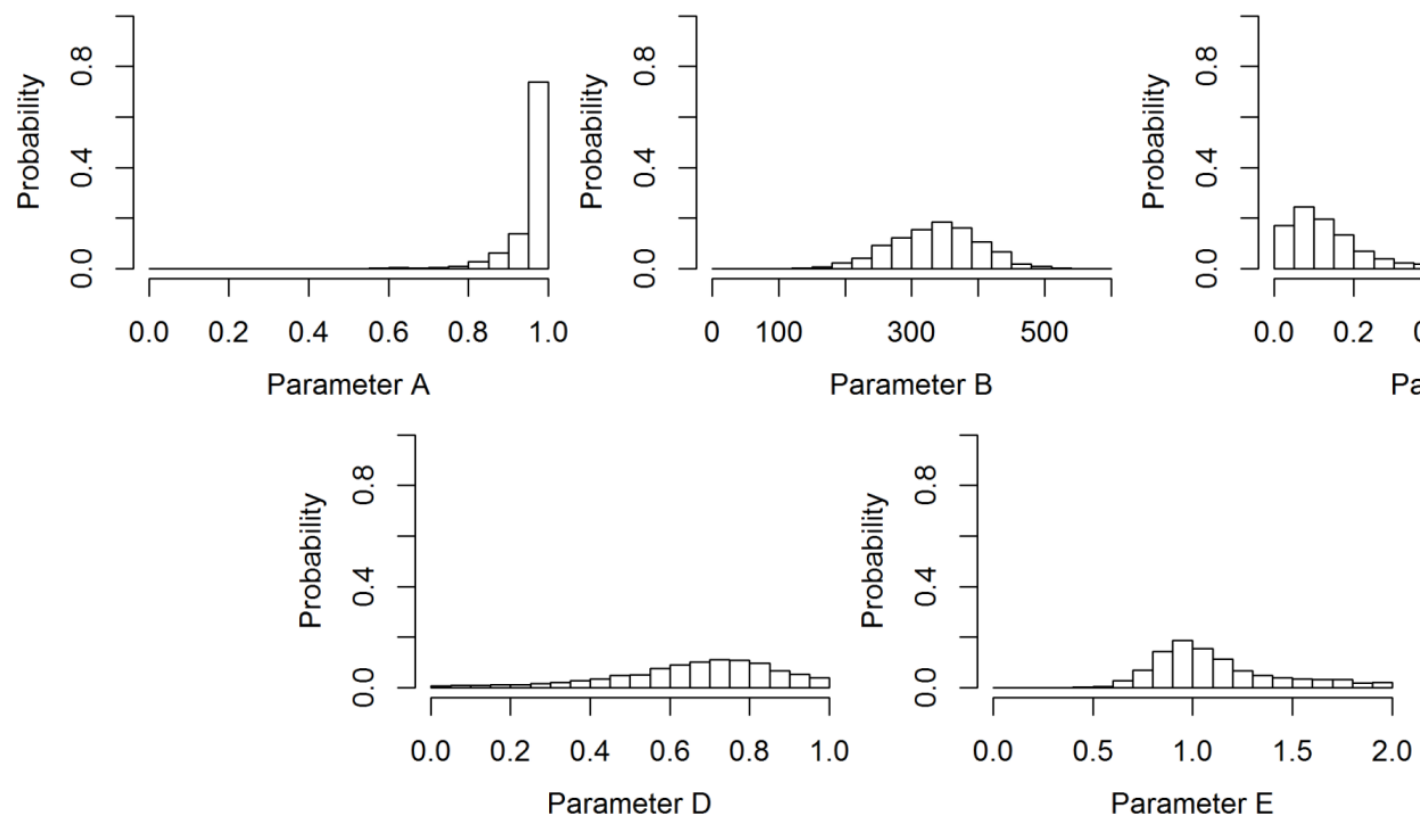

Figure 9: Posterior distributions of the ABCD model parameters. 
Hydrol. Earth Syst. Sci. Discuss., doi:10.5194/hess-2016-160, 2016 Manuscript under review for journal Hydrol. Earth Syst. Sci.

Published: 7 July 2016

(c) Author(s) 2016. CC-BY 3.0 License.
Hydrology and

Earth System

Sciences

Discussions
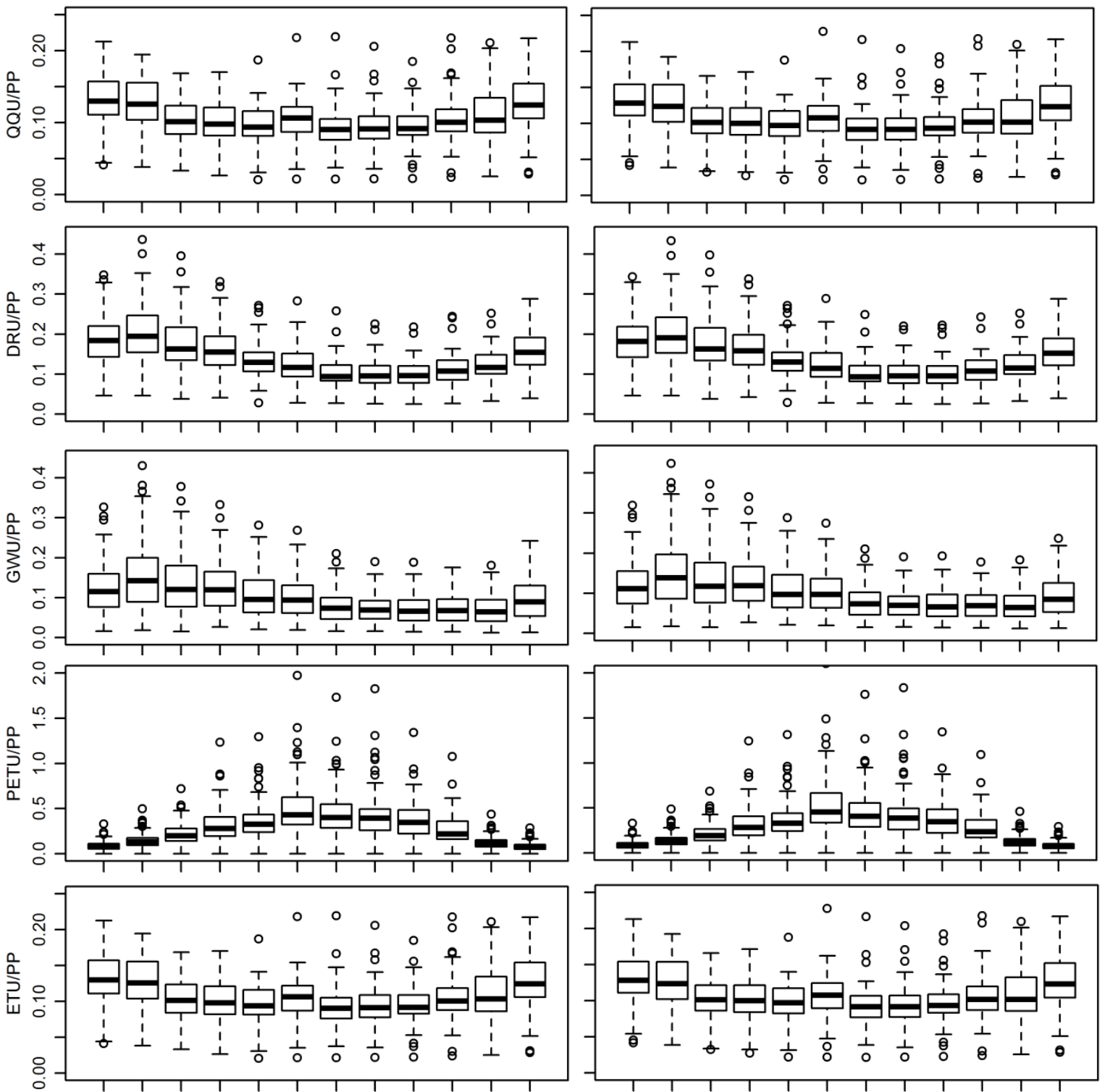
Hydrol. Earth Syst. Sci. Discuss., doi:10.5194/hess-2016-160, 2016

Manuscript under review for journal Hydrol. Earth Syst. Sci.

Published: 7 July 2016
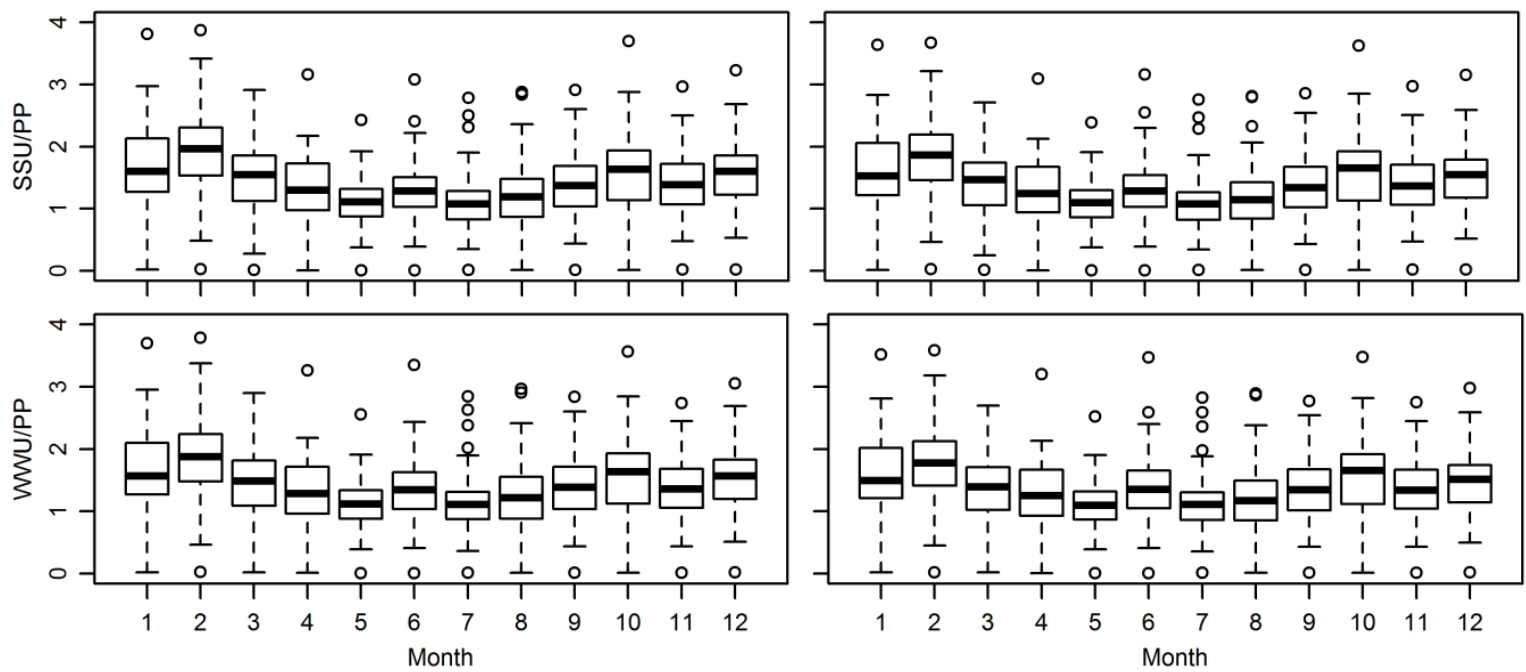

Figure 10: Watershed-wide variations of the uncertainty amounts in the projected hydrological components due to parameter selection (uncertainty in multi-parameter ensemble projections). Results for the RCP 4.5 and RCP 8.5 scenarios are placed in the left and right columns, respectively. XXU signifies the uncertainty $(U)$ of $X X$ in the unit of XX (mm). 

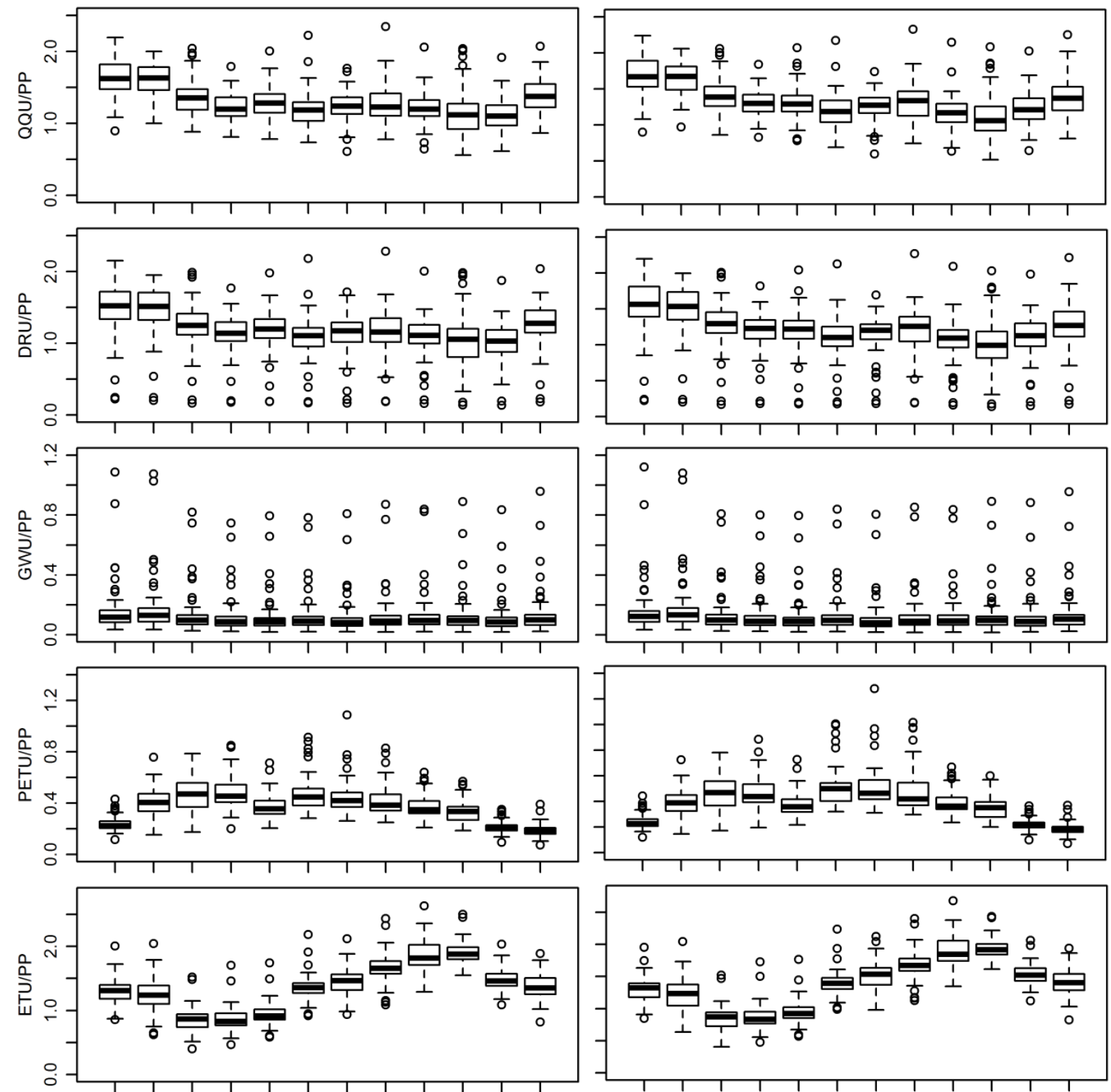
Hydrol. Earth Syst. Sci. Discuss., doi:10.5194/hess-2016-160, 2016

Manuscript under review for journal Hydrol. Earth Syst. Sci.

Published: 7 July 2016

(c) Author(s) 2016. CC-BY 3.0 License.

(c) (i)
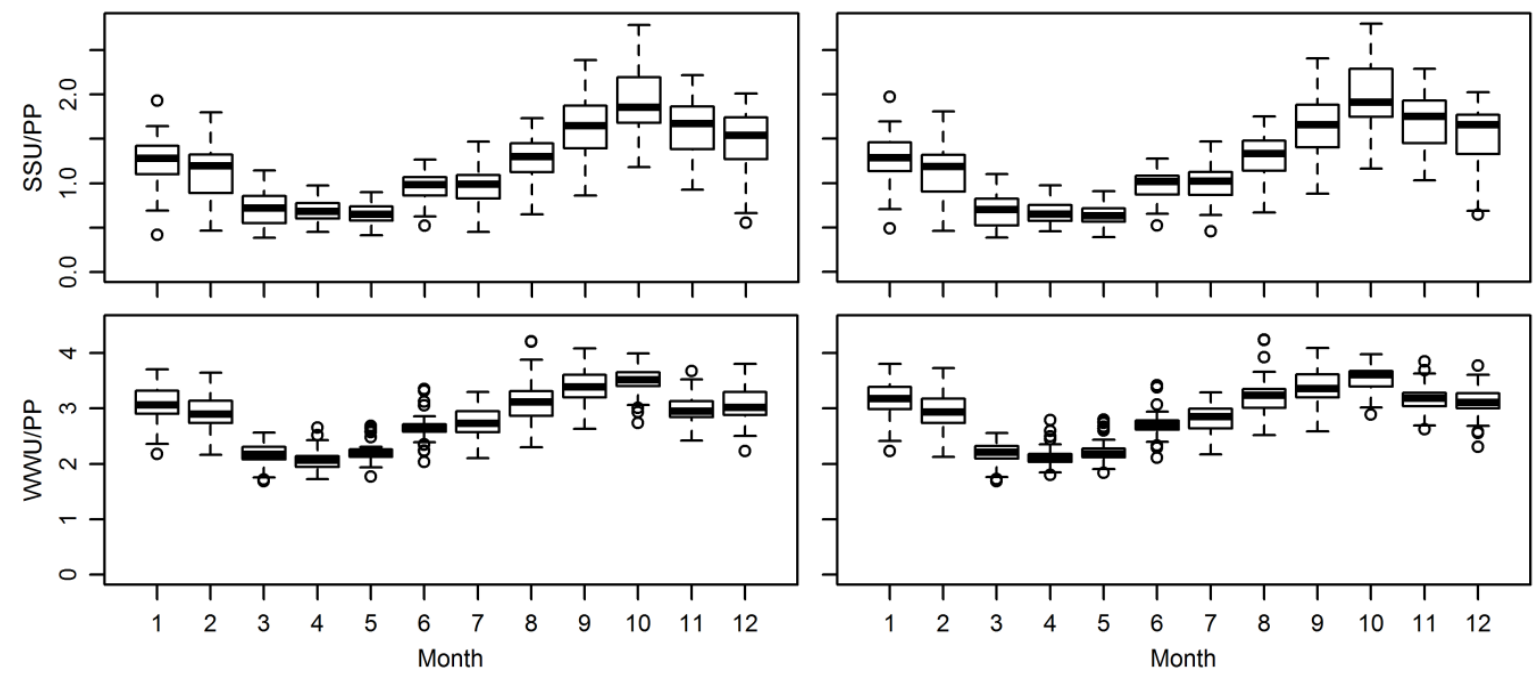

Figure 11: Watershed-wise variations of the uncertainty amounts in the projected hydrological components due to GCM selection (uncertainty in multi-GCM ensemble projections). Results for the RCP 4.5 and RCP 8.5 scenarios are placed in the left and right columns, respectively. XXU signifies the uncertainty $(U)$ of $X X$ in the unit of $X X(\mathrm{~mm})$. 
Hydrol. Earth Syst. Sci. Discuss., doi:10.5194/hess-2016-160, 2016

Manuscript under review for journal Hydrol. Earth Syst. Sci.

Published: 7 July 2016

(c) Author(s) 2016. CC-BY 3.0 License.
Hydrology and Earth System Sciences

Discussions (c) $\underset{\mathrm{By}}{\mathrm{B}}$

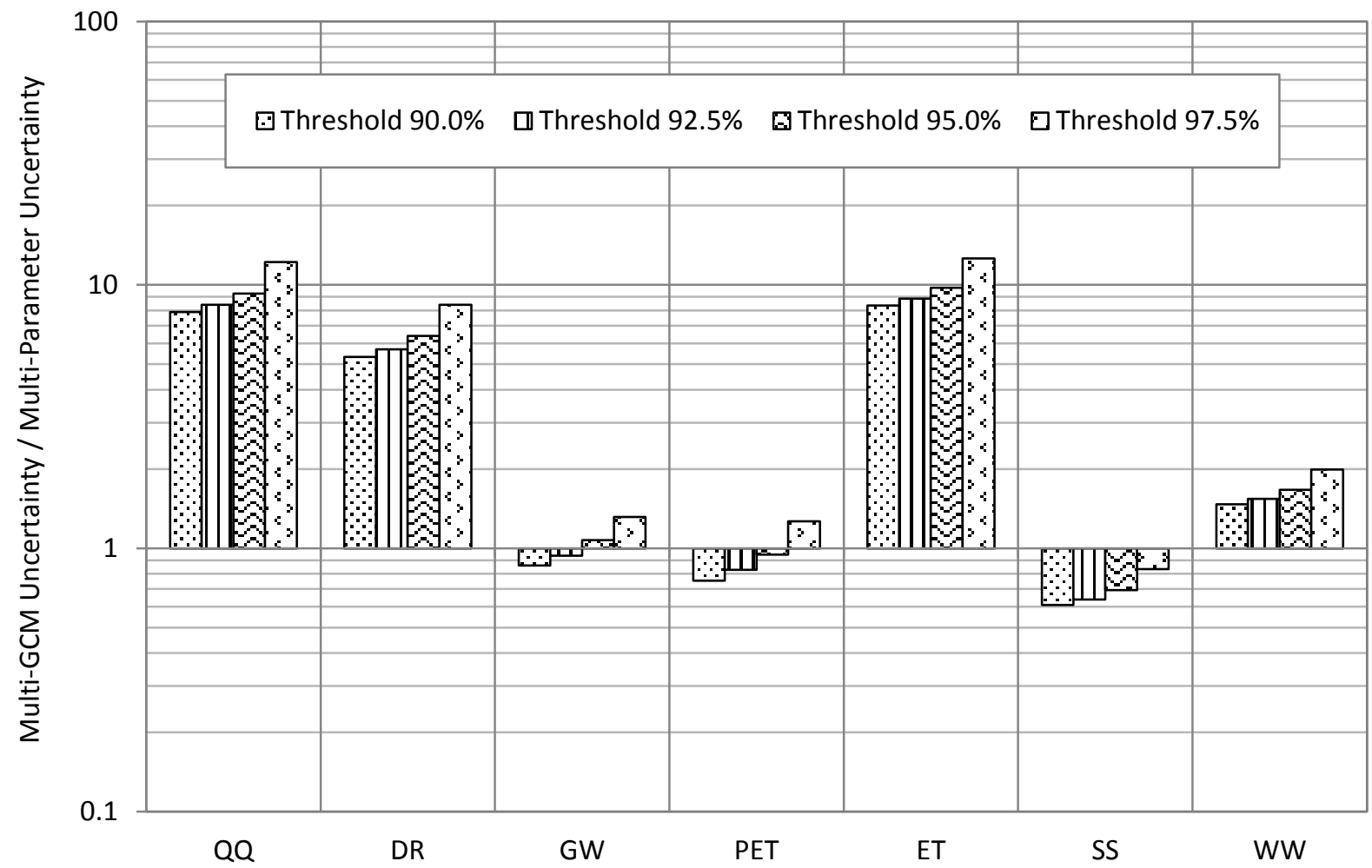

Figure 12: Sensitivity of the quantified uncertainty in multi-parameter ensembles for hydrologic components. 
Hydrol. Earth Syst. Sci. Discuss., doi:10.5194/hess-2016-160, 2016

Manuscript under review for journal Hydrol. Earth Syst. Sci.

Published: 7 July 2016

(c) Author(s) 2016. CC-BY 3.0 License.

\section{(c) (1)}
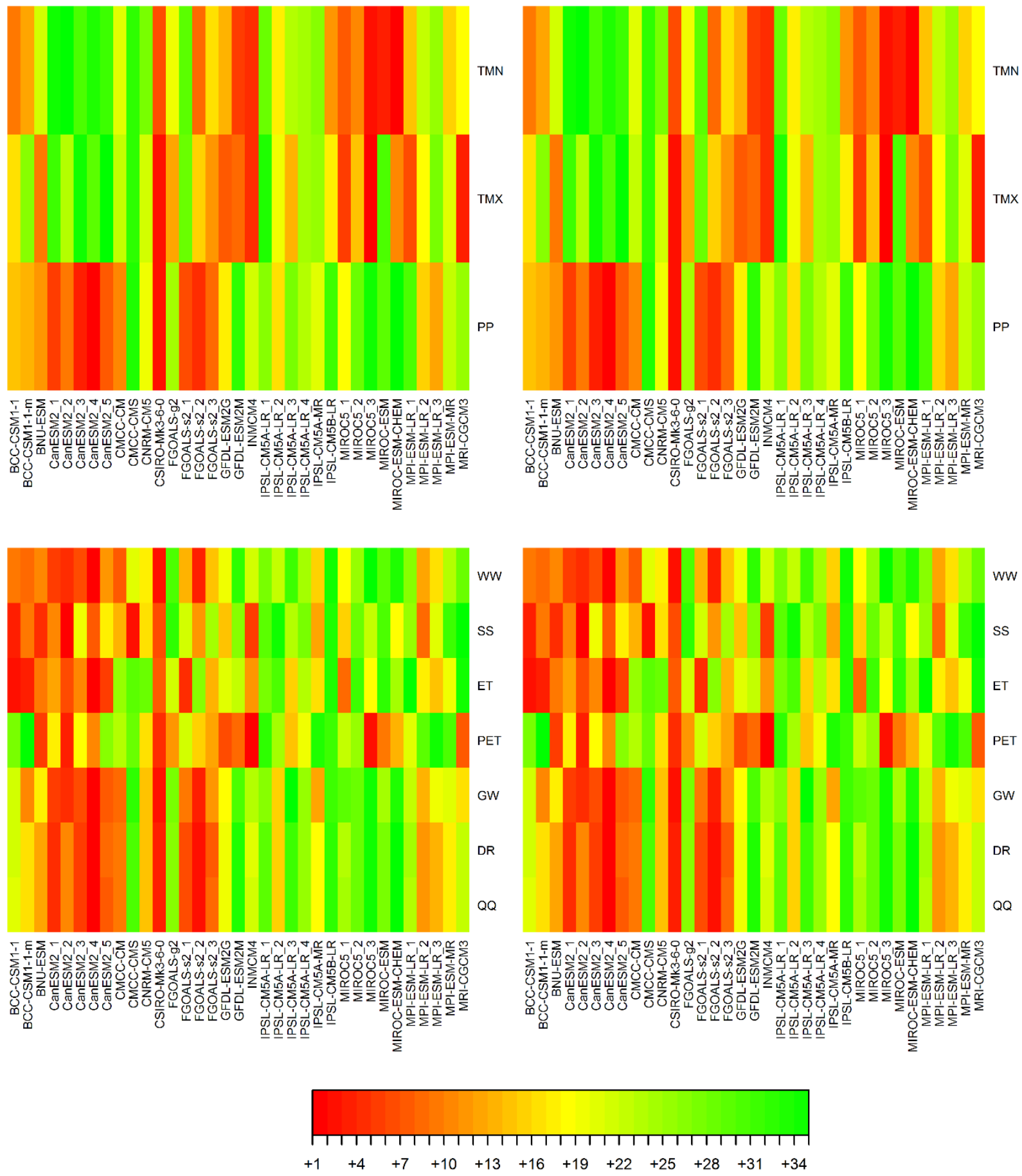

Figure 13: Rankings of the GCM contributions to the uncertainty amounts in the multi-GCM-ensemble projections for climate 5 variables and hydrologic components. Results for the RCP 4.5 and RCP 8.5 scenarios are placed in the left and right columns, respectively. 
Hydrol. Earth Syst. Sci. Discuss., doi:10.5194/hess-2016-160, 2016 Manuscript under review for journal Hydrol. Earth Syst. Sci.

Published: 7 July 2016

(c) Author(s) 2016. CC-BY 3.0 License.
Hydrology and

Earth System

Sciences

Discussions

\section{(c) $($ i)}
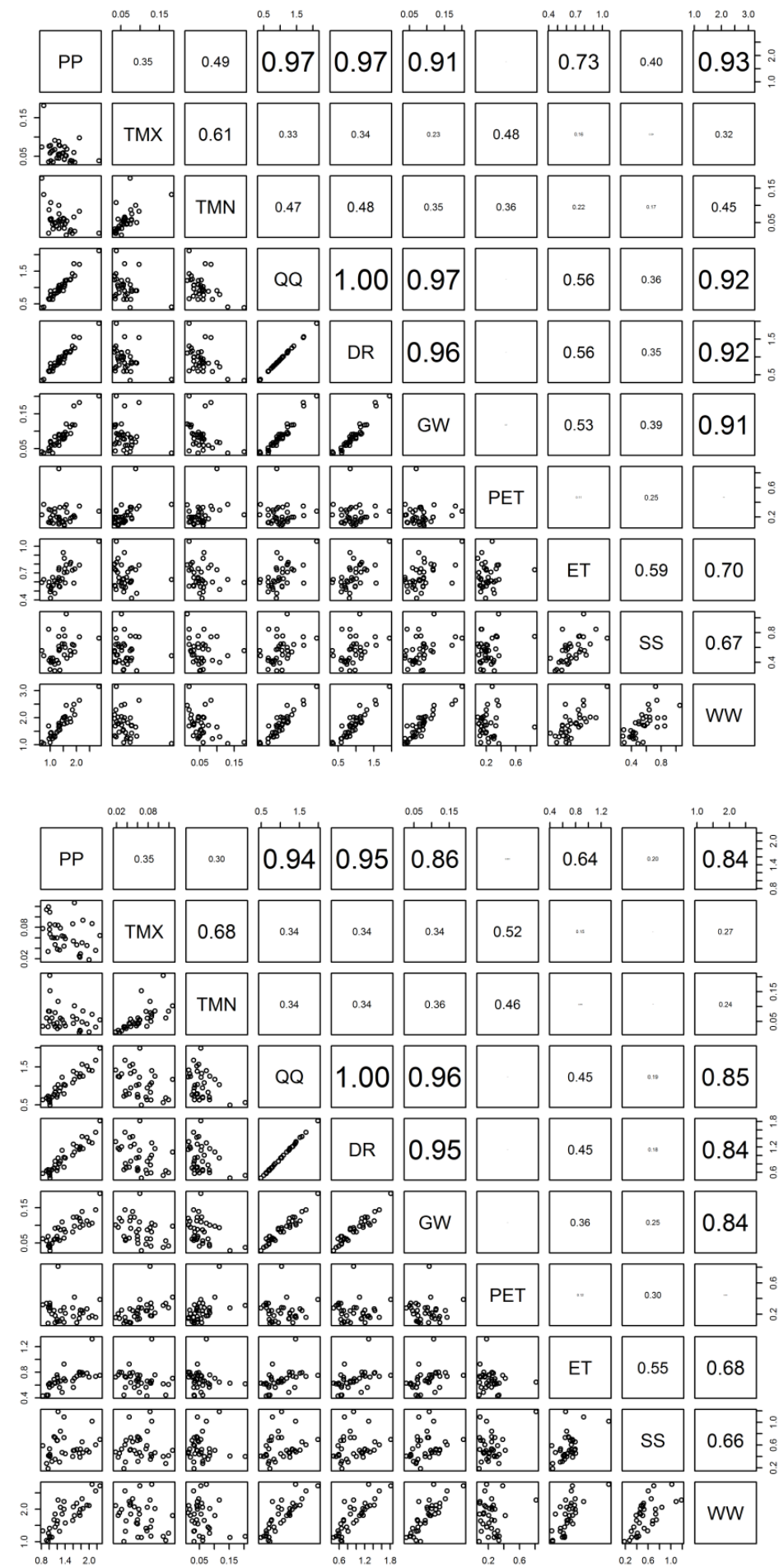

Figure 14: Correlation between the uncertainty amounts in the projections for climate variables and the projections for hydrologic components: (a) RCP 4.5 and (b) RCP 8.5. 
Hydrol. Earth Syst. Sci. Discuss., doi:10.5194/hess-2016-160, 2016

Manuscript under review for journal Hydrol. Earth Syst. Sci.

Table 1: The Coupled Model Intercomparison Project Phase 5 (CMIP5) GCM models, and their variants, used in this study (http://cmip-pcmdi.llnl.gov/cmip5/availability.html).

\begin{tabular}{|c|c|c|c|c|c|}
\hline Model name & $\begin{array}{c}\text { Realization } \\
\text { number* }\end{array}$ & ID number & Institute ID & Resolution & Country \\
\hline BCC-CSM1.1 $^{1)}$ & 1 & 1 & \multirow{2}{*}{$\mathrm{BCC}$} & $64 \times 128$ & \multirow{2}{*}{ China } \\
\hline BCC-CSM1.1-m ${ }^{1)}$ & 1 & 2 & & $160 \times 320$ & \\
\hline BNU-ESM $^{1)}$ & 1 & 3 & GCESS & $64 \times 128$ & China \\
\hline CanESM2 $^{1)}$ & $1,2,3,4,5$ & $4-8$ & CCCMA & $64 \times 128$ & Canada \\
\hline${\mathrm{CMCC}-\mathrm{CMS}^{2)}}^{2}$ & 1 & 9 & \multirow{2}{*}{$\mathrm{CMCC}$} & $96 \times 192$ & Italy \\
\hline $\mathrm{CMCC}^{-\mathrm{CM}^{2}}$ & 1 & 10 & & $240 \times 480$ & Italy \\
\hline $\mathrm{CNRM}^{-\mathrm{CM}^{2}}{ }^{2}$ & 1 & 11 & CNRM-CERFACS & $128 \times 256$ & France \\
\hline CSIRO-Mk3.6.0 & 1 & 12 & CSIRO-QCCCE & $96 \times 192$ & Australia \\
\hline FGOALS-g2 $^{1)}$ & 1 & 13 & LASG-IAP & \multirow{2}{*}{$108 \times 128$} & \multirow{2}{*}{ China } \\
\hline FGOALS-s $2^{1)}$ & $1,2,3$ & $14-16$ & LASG-CESS & & \\
\hline GFDL-ESM2G $^{1)}$ & 1 & 17 & \multirow{2}{*}{ NOAA GFDL } & \multirow{2}{*}{$90 \times 144$} & \multirow{2}{*}{ USA } \\
\hline GFDL-ESM2M $^{1)}$ & 1 & 18 & & & \\
\hline INM-CM4 $^{1)}$ & 1 & 19 & INM & $120 \times 180$ & Russia \\
\hline IPSL-CM5A-LR $^{1)}$ & $1,2,3,4$ & $20-23$ & \multirow{3}{*}{ IPSL } & $96 \times 96$ & \multirow{3}{*}{ France } \\
\hline IPSL-CM5A-MR $^{1)}$ & 1 & 24 & & $143 \times 144$ & \\
\hline IPSL-CM5B-LR ${ }^{1)}$ & 1 & 25 & & $96 \times 96$ & \\
\hline MIROC5 $^{1)}$ & $1,2,3$ & $26-28$ & \multirow{3}{*}{ MIROC } & $128 \times 256$ & \multirow{3}{*}{ Japan } \\
\hline MIROC-ESM ${ }^{2)}$ & 1 & 29 & & $64 \times 128$ & \\
\hline MIROC-ESM-CHEM ${ }^{2)}$ & 1 & 30 & & $04 \times 1 \angle 8$ & \\
\hline MPI-ESM-LR ${ }^{2)}$ & $1,2,3$ & $31-33$ & \multirow{2}{*}{ MPI-M } & \multirow{2}{*}{$96 \times 192$} & \multirow{2}{*}{ Germany } \\
\hline MPI-ESM-MR ${ }^{2)}$ & 1 & 34 & & & \\
\hline MRI-CGCM3 $^{2)}$ & 1 & 35 & MRI & $160 \times 320$ & Japan \\
\hline
\end{tabular}

1) calendar: 365 days (without a leap day)

2) calendar: Standard (with a leap day)

5 * "realization" number is used to distinguish among members of an ensemble typically generated by initializing a set of runs with different, but equally realistic, initial conditions. 
Hydrol. Earth Syst. Sci. Discuss., doi:10.5194/hess-2016-160, 2016

Manuscript under review for journal Hydrol. Earth Syst. Sci.

Published: 7 July 2016

(C) Author(s) 2016. CC-BY 3.0 License.
Hydrology and

Earth System

Sciences

Discussions (c) (1)

Table 2: Overall changes of the climate variables and hydrologic components projected by the multi-GCM, multi-parameter, and multi-watershed ensembles.

\begin{tabular}{|c|c|c|c|c|}
\hline Variables & Statistics & Historical & RCP 4.5 & RCP 8.5 \\
\hline \multirow{2}{*}{ Temperature (TAV) } & Average $\left({ }^{\circ} \mathrm{C}\right)$ & 12.0 & 14.2 & 15.6 \\
\hline & Projected Change & - & $2.2 \%$ & $3.6 \%$ \\
\hline \multirow{2}{*}{ Precipitation (PP) } & Average (mm) & $1,084.9$ & $1,159.0$ & $1,180.0$ \\
\hline & Projected Change & - & $6.8 \%$ & $8.8 \%$ \\
\hline \multirow{2}{*}{ Total runoff (QQ) } & Average $(\mathrm{mm})$ & 402.5 & 442.7 & 451.9 \\
\hline & Projected Change & - & $10.0 \%$ & $12.3 \%$ \\
\hline $\mathrm{QQ} / \mathrm{PP}$ & Projected Change & $37.1 \%$ & $38.2 \%$ & $38.3 \%$ \\
\hline \multirow{2}{*}{ Direct runoff (DR) } & Average $(\mathrm{mm})$ & 337.8 & 372.2 & 380.2 \\
\hline & Projected Change & - & $10.2 \%$ & $12.6 \%$ \\
\hline $\mathrm{DR} / \mathrm{QQ}$ & Projected Change & $83.9 \%$ & $84.1 \%$ & $84.1 \%$ \\
\hline \multirow{2}{*}{ Groundwater (GW) } & Average $(\mathrm{mm})$ & 62.1 & 67.8 & 69.1 \\
\hline & Projected Change & - & $9.2 \%$ & $11.3 \%$ \\
\hline \multirow{2}{*}{ Evapotranspiration (ET) } & Average $(\mathrm{mm})$ & 682.4 & 716.5 & 728.0 \\
\hline & Projected Change & - & $5.0 \%$ & $6.7 \%$ \\
\hline $\mathrm{ET} / \mathrm{PP}(=1-\mathrm{QQ} / \mathrm{PP})$ & Projected Change & $62.9 \%$ & $61.8 \%$ & $61.7 \%$ \\
\hline \multirow{2}{*}{ Potential ET (PET) } & Average $(\mathrm{mm})$ & $1,085.3$ & $1,154.4$ & $1,183.1$ \\
\hline & Projected Change & - & $6.4 \%$ & $9.0 \%$ \\
\hline \multirow{2}{*}{ Soil Moisture (SS) } & Average $(\mathrm{mm})$ & $2,558.4$ & $2,535.6$ & $2,510.4$ \\
\hline & Projected Change & - & $-0.9 \%$ & $-1.9 \%$ \\
\hline \multirow{2}{*}{ Available Water (WW) } & Average $(\mathrm{mm})$ & $3,634.8$ & $3,691.2$ & $3,687.6$ \\
\hline & Projected Change & - & $1.6 \%$ & $1.5 \%$ \\
\hline
\end{tabular}


Hydrol. Earth Syst. Sci. Discuss., doi:10.5194/hess-2016-160, 2016

Manuscript under review for journal Hydrol. Earth Syst. Sci.

Published: 7 July 2016

(c) Author(s) 2016. CC-BY 3.0 License.
Hydrology and

Earth System

Sciences

Discussions

(c) (i)

Table 3: Projected percentage changes (projection period of 2020 to 2099 vs. historical period of 1980 to 2000 ) of the hydrologic components of the study watersheds: the multi-GCM, multi-parameter and multi-watershed ensemble projections for the Ohio River watersheds (unit: dimensionless ratio, projected data/historical data).

\begin{tabular}{|c|c|c|c|c|c|c|c|c|c|c|c|c|c|}
\hline Item & $\mathrm{RCP}$ & Jan & Feb & Mar & Apr & May & Jun & Jul & Aug & Sep & Oct & Nov & Dec \\
\hline \multirow{2}{*}{ PP } & 4.5 & 8.49 & 9.86 & 9.64 & 11.55 & 7.39 & 3.72 & 3.64 & 5.83 & 6.84 & 5.25 & 5.64 & 6.49 \\
\hline & 8.5 & 12.69 & 15.2 & 17.04 & 14.81 & 8.50 & 1.58 & 3.98 & 8.23 & 8.00 & 4.25 & 5.46 & 9.63 \\
\hline \multirow{2}{*}{ QQ } & 4.5 & 10.67 & 10.83 & 10.45 & 12.62 & 10.09 & 6.15 & 7.67 & 12.39 & 13.01 & 10.54 & 7.33 & 7.69 \\
\hline & 8.5 & 13.69 & 14.73 & 18.28 & 17.47 & 11.20 & 2.46 & 6.36 & 16.24 & 13.61 & 7.93 & 7.00 & 7.94 \\
\hline \multirow{2}{*}{ DR } & 4.5 & 11.66 & 11.32 & 10.64 & 12.96 & 10.03 & 5.40 & 7.50 & 13.45 & 13.72 & 10.54 & 7.00 & 7.58 \\
\hline & 8.5 & 15.03 & 15.5 & 18.91 & 17.78 & 10.72 & 0.53 & 5.85 & 18.03 & 14.09 & 7.26 & 6.62 & 7.88 \\
\hline \multirow{2}{*}{ GW } & 4.5 & 1.43 & 5.71 & 8.12 & 10.14 & 10.19 & 8.87 & 8.46 & 9.88 & 10.69 & 10.87 & 9.24 & 8.60 \\
\hline & 8.5 & 1.79 & 7.67 & 13.06 & 15.07 & 13.47 & 9.98 & 8.74 & 11.31 & 11.81 & 10.61 & 9.00 & 8.67 \\
\hline \multirow{2}{*}{ PET } & 4.5 & 12.9 & 12.65 & 10.83 & 8.28 & 5.96 & 5.12 & 4.11 & 4.22 & 5.65 & 7.62 & 10.16 & 10.41 \\
\hline & 8.5 & 18.39 & 16.43 & 13.71 & 11.18 & 8.70 & 7.70 & 6.19 & 5.92 & 7.71 & 11.57 & 14.74 & 15.03 \\
\hline \multirow{2}{*}{ ET } & 4.5 & 5.54 & 8.07 & 8.32 & 10.45 & 5.62 & 2.68 & 2.44 & 4.27 & 5.43 & 3.86 & 5.01 & 5.64 \\
\hline & 8.5 & 11.34 & 16.2 & 14.87 & 12.09 & 6.76 & 1.18 & 3.35 & 6.33 & 6.75 & 3.28 & 4.91 & 10.9 \\
\hline \multirow{2}{*}{ SS } & 4.5 & 1.28 & 0.51 & -0.66 & -1.38 & -2.06 & -2.93 & -2.81 & -2.08 & -1.36 & -1.42 & \begin{tabular}{|c|}
-0.78 \\
\end{tabular} & -0.37 \\
\hline & 8.5 & 0.78 & 0.30 & -0.72 & -2.03 & -3.30 & -5.23 & -4.80 & -3.28 & -2.34 & -2.98 & -2.41 & -1.16 \\
\hline \multirow{2}{*}{ WW } & 4.5 & 3.36 & 2.98 & 2.88 & 2.81 & 1.69 & -0.01 & \begin{tabular}{|c|}
-0.18 \\
\end{tabular} & 0.61 & 1.21 & 0.75 & 0.88 & 1.13 \\
\hline & 8.5 & 3.67 & 3.68 & 4.62 & 3.68 & 1.67 & -1.57 & -1.34 & 0.38 & 0.86 & -0.25 & -0.23 & 0.75 \\
\hline
\end{tabular}

